\title{
Ligands of the antiestrogen-binding site induce active cell death and autophagy in human breast cancer cells through the modulation of cholesterol metabolism
}

\author{
P de Medina ${ }^{1,2,3,7}$, B Payré ${ }^{1,2,4,5,7}$, N Boubekeur ${ }^{1,2,4}$, J Bertrand-Michel ${ }^{6}$, F Tercé ${ }^{6}$, S Silvente-Poirot ${ }^{1,2,4,8}$ and M Poirot ${ }^{\star, 1,2,4}$
}

\begin{abstract}
We have recently reported that cytostatic concentrations of the microsomal antiestrogen-binding site (AEBS) ligands, such as PBPE (N-pyrrolidino-(phenylmethyphenoxy)-ethanamine, $\mathrm{HCl}$ ) and tamoxifen, induced differentiation characteristics in breast cancer cells through the accumulation of post-lanosterol intermediates of cholesterol biosynthesis. We show here that exposure of MCF-7 (human breast adenocarcinoma cell line) cells to higher concentrations of AEBS ligands triggered active cell death and macroautophagy. Apoptosis was characterized by Annexin V binding, chromatin condensation, DNA laddering and disruption of the mitochondrial functions. We determined that cell death was sterol- and reactive oxygen species-dependent and was prevented by the antioxidant vitamin E. Macroautophagy was characterized by the accumulation of autophagic vacuoles, an increase in the expression of Beclin-1 and the stimulation of autophagic flux. We established that macroautophagy was steroland Beclin-1-dependent and was associated with cell survival rather than with cytotoxicity, as blockage of macroautophagy sensitized cells to AEBS ligands. These results show that the accumulation of sterols by AEBS ligands in MCF-7 cells induces apoptosis and macroautophagy. Collectively, these data support a therapeutic potential for selective AEBS ligands in breast cancer management and shows a mechanism that explains the induction of autophagy in MCF-7 cells by tamoxifen and other selective estrogen receptor modulators.
\end{abstract}

Cell Death and Differentiation (2009) 16, 1372-1384; doi:10.1038/cdd.2009.62; published online 12 June 2009

PBPE (N-pyrrolidino-4-(phenylmethyphenoxyl)-ethanamine, $\mathrm{HCl})$ is a diphenylmethane derivative of tamoxifen (Tx) that selectively binds to the microsomal antiestrogen-binding site (AEBS) with high affinity. The AEBS was initially characterized as a secondary binding site for the antitumor and chemopreventive drug, Tx, along with estrogen receptors. ${ }^{1}$ The AEBS binds selective estrogen receptor modulators (SERM) that contain a cationic aminoethoxy side chain, but has no affinity for estrogens and non-cationic antiestrogens, such as Faslodex, ICl-164,384 and RU-58,668. ${ }^{2}$ A class of derivatives of $\mathrm{Tx}$ has been developed that bind to the AEBS with high affinity and selectively. This family of compounds includes as lead compounds tesmilifene (DPPE, $N, N^{\prime}$-diethylamino-4-(phenylmethylphenoxy)-ethanamine, $\left.\mathrm{HCl}\right)^{3}$ and PBPE. ${ }^{4}$ These compounds have no affinity for estrogen receptors and did not modulate other known targets of Tx such as acyl-coA:cholesterol acyltransferase and protein kinase $\mathrm{C},{ }^{5}$ allowing AEBS-related cellular events to be studied. Despite a lack of a clear understanding of its mechanism of action at that time, tesmilifene was evaluated for the treatment of breast and prostate cancer with some encouraging results in phase II and III clinical trials. ${ }^{6-8}$ However, a pivotal phase III trial was recently aborted because of the lack of a therapeutic outcome. This strongly reinforces the need to understand better the mechanism of action of drugs to optimize their clinical use.

The AEBS has been reported to bind unsaturated fatty acids and oxysterols (7-ketocholesterol, 7-ketocholestanol and 7-hydroxycholesterol), suggesting a link between the AEBS and the metabolism of lipids and sterols. This led us to identify the AEBS as a hetero-oligomeric complex composed of two subunits: the $3 \beta$-hydroxysterol- $\Delta^{7}$-reductase (DHCR7) and $3 \beta$-hydroxysterol- $\Delta^{8}-\Delta^{7}$-isomerase (D8D7I); these two enzymes are involved in post-lanosterol cholesterol biosynthesis. ${ }^{2}$ Binding to the AEBS of ligands, such as PBPE or Tx, inhibits these enzymes and induces the accumulation of their sterol substrates in breast cancer cells, which leads to the doubling of the unesterified sterol content in cells. ${ }^{2}$ We have linked this effect to the induction of growth control and differentiation of breast cancer cells. ${ }^{9}$ We showed that both AEBS ligands and sterols, which accumulate in cells through

\footnotetext{
${ }^{1}$ INSERM U563, Toulouse, France; ${ }^{2}$ Université Toulouse III Paul Sabatier, Toulouse, France; ${ }^{3}$ Affichem, Toulouse, France; ${ }^{4}$ Institut Claudius Regaud, Toulouse, France; ${ }^{5}$ Université Toulouse III Paul Sabatier, Faculté de Médecine Toulouse-Rangueil, Centre de Microscopie Electronique Appliquée à la Biologie, Toulouse, France and ${ }^{6}$ Plateau technique de lipidomique, IFR30, Genopole Toulouse, INSERM U563, Toulouse, France

${ }^{*}$ Corresponding author: M Poirot, INSERM, U-563, équipe Métabolisme, Oncogenèse et Différenciation Cellulaire, Centre de Physiopathologie de Toulouse Purpan, Institut Claudius Regaud, 24 rue du pont Saint Pierre, Toulouse, Cedex F-31052, France.

Tel: + 335 61424648; Fax: + 335 61424631; E-mail: Marc_Poirot@ hotmail.com

${ }^{7}$ These authors contributed equally to this work.

${ }^{8}$ Sandrine Silvente-Poirot is in charge of research at the CNRS.

Keywords: AEBS; PBPE; tamoxifen; cytotoxicity; zymostenol; desmosterol; oxysterols

Abbreviations: AEBS, antiestrogen-binding site; AIF, apopotosis-inducing factor; Tx, tamoxifen; 4OHTx, 4-hydroxytamoxifen; PBPE, N-pyrrolidino-(phenylmethyphenoxy)-ethanamine,HCl; DPPE, $N, N$-diethylamino-(phenylmethylphenoxy-ethanamine,HCl; CHX, cycloheximide; Act D, actinomycin D; vit E, vitamin E; NAC, $N$ acetylcysteine; BHT, butylated hydroxytoluene; zymostenol, $5 \alpha$-cholest-8-en-3 $\beta$ ol; desmosterol, $5 \alpha$-cholest-5,24-dien-3 $\beta$ ol; zymosterol, $5 \alpha$-cholest-8,24-dien-3 $\beta$ ol Received 20.10.08; revised 27.4.09; accepted 27.4.09; Edited by D Klionsky; published online 12.6.09
} 
the inhibition of enzymes that constitute the AEBS, induced the arrest of cells in the G0-G1 phase of the cell cycle, and stimulated the expression and the secretion of a protein found in milk (the milk fat globulin). They also stimulated the production of lipids found in milk, such as sphingomyelin and triglycerides. We showed that the antioxidant vitamin $E$ (vit E, $\alpha$-tocopherol) completely blocked the effects of AEBS ligands by protecting sterols against oxidation, indicating that reactive oxygen species (ROS) were important in these effects. ${ }^{9}$ Moreover, we showed that both longer exposure of cancer cells to AEBS ligands and higher concentrations induced cytotoxicity, ${ }^{9,10}$ but the nature of the cell death has not been studied.

The aim of this study was to further characterize the nature of the cytotoxicity induced by AEBS ligands on breast cancer cells.

\section{Results}

PBPE induced active cell death in MCF-7 cells. We have reported in an earlier paper that PBPE and Tx induced time- and concentration-dependent growth control through a cell-cycle arrest in the G0-G1 phase in MCF-7 (human breast adenocarcinoma cell line) cells. ${ }^{9}$ We report here that increasing the concentration of PBPE and Tx induced timedependent cell death (Figure 1A) and diminished cell survival in a clonogenic assay, inducing 66 and $36.6 \%$ reduction, respectively, in the number of colonies (Figure 1B). To observe early events in apoptosis, we next examined the exposure of phosphatidylserine at the cell surface by using Annexin V/propidium iodide (PI) double staining. Flow cytometric analysis showed that the percentage of Annexin V-positive cells increased with time of exposure to PBPE or $\mathrm{Tx}$ in treated cells (Figure 1C). The accumulation of Annexin V-positive/PI-negative cells culminated at $82 \pm 7 \%$ with $40 \mu \mathrm{M}$ PBPE and at $64 \pm 5 \%$ with $10 \mu \mathrm{M}$ Tx for 3 days of treatment. For each treatment, we observed the progressive appearance of Annexin V-positive/PI-positive cells that culminated at $15 \pm 2 \%$ and $30 \pm 4 \%$ after 3 days of treatment with $40 \mu \mathrm{M}$ PBPE and $10 \mu \mathrm{M}$ Tx, respectively. This established that PBPE and Tx treatment induced the exposure of phosphatidylserine at the surface of most treated cells. Morphological characteristics were then studied by fluorescence microscopy after cells were exposed to solvent vehicle, $40 \mu \mathrm{M}$ PBPE and $10 \mu \mathrm{M}$ Tx, and were stained with 4',6-diamino-2-phenylindole (DAPI). Control cells showed an even distribution of the stain and round homogeneous nuclei (Figure 1D(a)). Cells treated with PBPE (Figure 1D(b)) or with $\mathrm{Tx}$ (Figure $1 \mathrm{D}(\mathrm{c})$ ) displayed changes typical of apoptosis, including reduction in the cell volume, bright staining, condensed, pycnotic and crescent nuclei. The analyses of the genomic DNA showed that treating the cells with $40 \mu \mathrm{M}$ PBPE, $40 \mu \mathrm{M}$ DPPE or $10 \mu \mathrm{M}$ Tx induced DNA laddering mainly in detached cells and, to a lesser extent, in adherent cells (Figure 1E). In the next set of experiments, we investigated the impact of various pharmacological inhibitors of active cell death on PBPE and Tx induced cytotoxicity. MCF-7 cells are known to be deficient in caspase 3 , but other executioner caspases such as caspase 6 or 7 have been reported to be active in MCF-7 cells. ${ }^{11}$ Cells were preincubated with $100 \mu \mathrm{M}$ z-VAD-fmk (a cell-permeable inhibitor of caspases 1, 3, 4 and 7) or with $100 \mu \mathrm{M}$ z-DEVD-fmk (a cell-permeable inhibitor of caspases 3, 6, 8 and 10) and then treated for 3 days with $40 \mu \mathrm{M}$ PBPE or with $10 \mu \mathrm{M} \mathrm{Tx}$. The results established that general caspase inhibitors failed or had little impact on inhibiting the cell death caused by PBPE and Tx in MCF-7 cells (Figure 1F), showing that executioner caspases were not involved. Pre-incubation of cells with cycloheximide $(\mathrm{CHX})$ (an inhibitor of the translation of mRNA) or with actinomycin D (Act D) (an inhibitor of gene transcription) protected MCF-7 cells against PBPE or Tx, showing that gene transcription and translation were required during cell death. Altogether, these data showed that the selective AEBS ligands, PBPE and Tx, induced active cell death.

PBPE and Tx induced alterations of the mitochondria in MCF-7 cells. We next evaluated the impact of PBPE and of $T x$ on the mitochondria. These changes include a reduction in the inner mitochondrial membrane transmembrane potential $\left(\Delta \Psi_{\mathrm{m}}\right)$, a modification of the expression of mitochondrial anti-apoptotic proteins $(\mathrm{Bcl}-2)$ and pro-apoptotic proteins (Bax), and the translocation of proteins such as cytochrome $c$ and the caspase-independent effector apoptosis-inducing factor (AIF) from the mitochondria. Using DiOC6(3) staining and flow cytometry, we analyzed the $\Delta \Psi_{\mathrm{m}}$ in PBPE- and Tx-treated MCF-7 cells. Three days exposure of MCF-7 cells to $40 \mu \mathrm{M}$ PBPE or to $10 \mu \mathrm{M}$ Tx reduced the $\Delta \Psi_{\mathrm{m}}$, indicating a depolarization of the mitochondrial membrane (Figure 2A). We next analyzed the expression of $\mathrm{Bcl}-2$ and Bax proteins in treated cells by western blotting. In Figure $2 \mathrm{~B}$, it can be seen that PBPE strongly stimulates the expression of Bax at day 3 and, to a lesser extent, the expression of Bcl-2. The resulting balance is strongly in favor of the pro-apoptotic protein Bax. We showed that $\mathrm{Tx}$ reduced the expression of $\mathrm{Bcl}-2$ and stimulated the expression of Bax, leading to a modification of the $\mathrm{Bcl}-2 / \mathrm{Bax}$ ratio in favor of Bax (Figure 2B). This shows that both treatments reduced the $\mathrm{Bcl}-2 / \mathrm{Bax}$ ratio. We show in Figure 2B that the expression of $\mathrm{P} 53$ or p21waf was not modulated by PBPE or Tx, showing that p53 was not involved in the regulation of Bax expression. The importance of $\mathrm{Bcl}-2$ was confirmed by showing that MCF-7 cells overexpressing Bcl-2 were 10 times less sensitive than mocktransfected cells to PBPE and Tx induction of cytoxicity (Figure 2C). Quantification of the amount of AEBS showed no significant difference between MCF-7 cells $\left(K_{\mathrm{d}}=5.3 \pm\right.$ $1.9 \mathrm{nM}, B_{\max }=1534 \pm 69 \mathrm{pmol}$ per $\mathrm{mg}$ microsomal proteins) and MCF-7/Bcl-2 $\left(K_{\mathrm{d}}=5.2 \pm 2.1 \mathrm{nM}, B_{\max }=1627 \pm 82 \mathrm{pmol}\right.$ per $\mathrm{mg}$ microsomal proteins) or MCF-7/Neo $\left(K_{\mathrm{d}}=5.2 \pm\right.$ $2.1 \mathrm{nM}, B_{\max }=1567 \pm 55 \mathrm{pmol}$ per mg microsomal proteins), and cells exhibit the same sterol profile as MCF-7 cells (data not shown). The loss of $\Delta \Psi_{\mathrm{m}}$ and the diminution of the $\mathrm{Bcl}-2 /$ Bax ratio observed in PBPE- and Tx-treated MCF-7 cells were associated with the release of cytochrome $c$ into the cytoplasm as measured by western blotting (Figure 2B). We next examined the translocation of AIF from the mitochondria to the nucleus by confocal microscopy. As shown in Figure 2D, treatment of MCF-7 cells with PBPE and Tx 
A

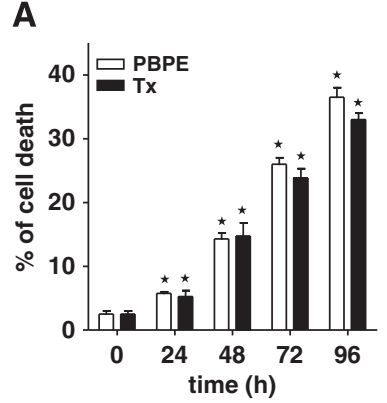

B

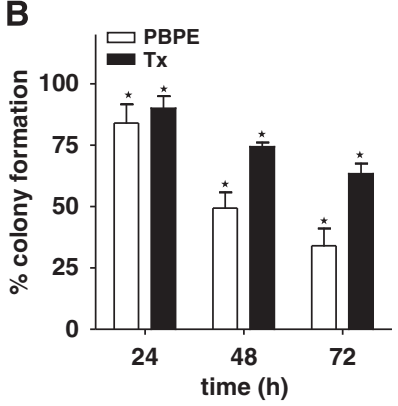

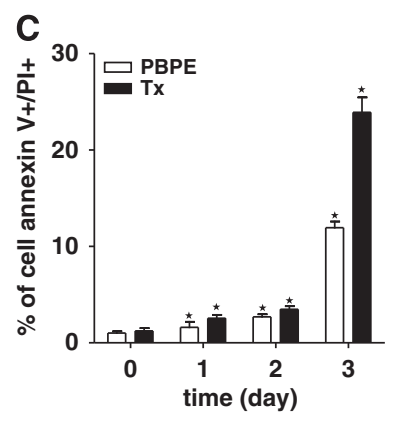

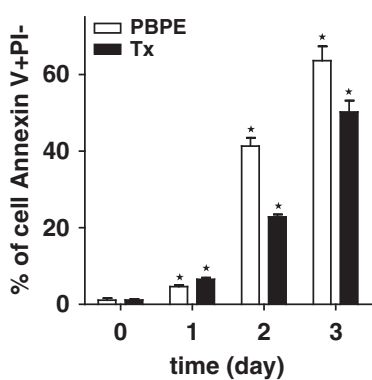

D
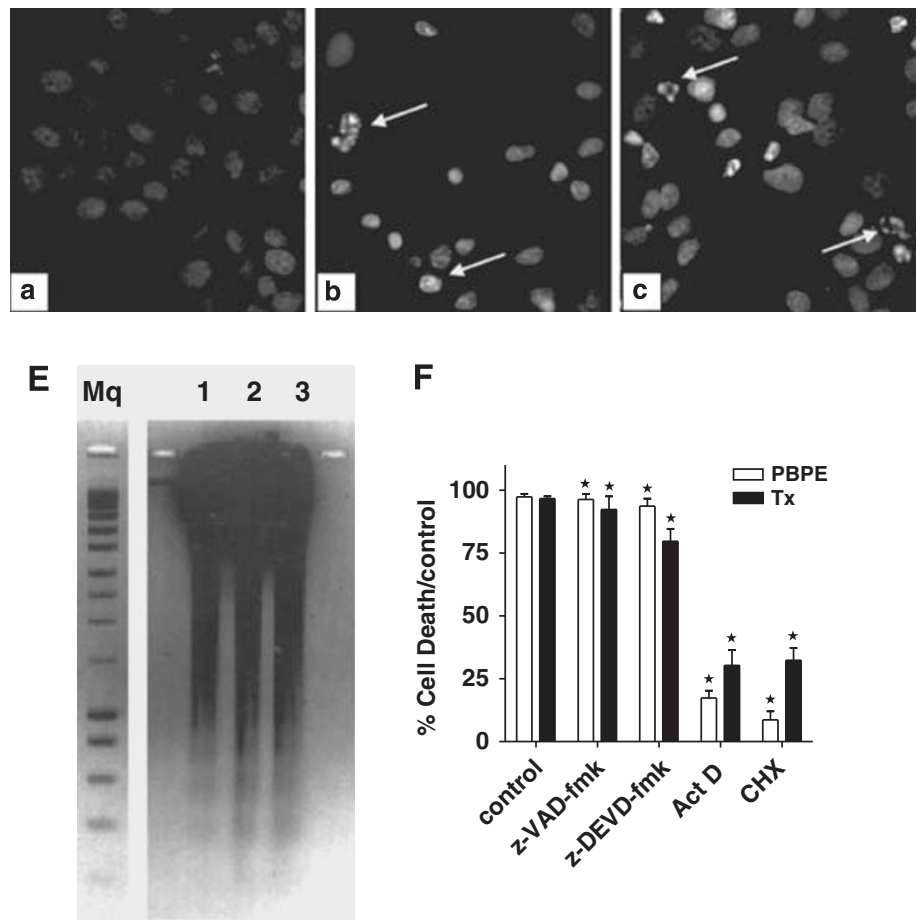

$\mathbf{F}$

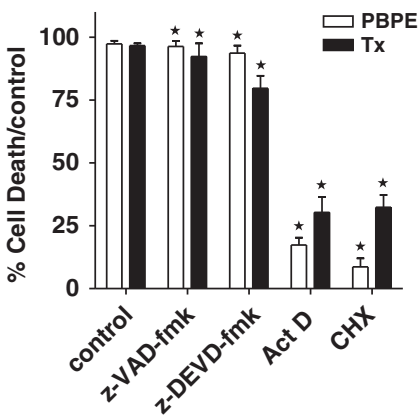

Figure 1 PBPE and Tx induced active cell death in MCF-7 cells. (A) Time course study of cell death induction by PBPE and Tx. Cell death was determined by the Trypan blue exclusion test. Cells were treated with solvent vehicle, $40 \mu \mathrm{M}$ PBPE or $10 \mu \mathrm{M} \mathrm{Tx}$. Data were expressed as the percentage of cell death relative to total cells. Data were normalized to solvent vehicle-treated cells (taken to be $0 \%$ ). (B) Effect of PBPE and Tx on colony formation. Cells were treated with solvent vehicle, $40 \mu \mathrm{M}$ PBPE or $10 \mu \mathrm{M}$ Tx, and the number of colonies was measured compared with solvent vehicle-treated cells (taken to be 100\%). (C) Effect of PBPE and Tx on the production of Annexin-V positive and propidium iodide (PI)-positive and -negative cells. MCF-7 cells were treated up to 3 days with $40 \mu \mathrm{M}$ PBPE or with $10 \mu \mathrm{M} \mathrm{Tx}$. Cells were stained with Annexin V-FITC and $\mathrm{PI}$ and analyzed by flow cytometry. (D) Detection of PBPE and Tx induced chromatin condensation cell death in MCF-7 cells by 4',6-diamino-2-phenylindole (DAPI) staining. MCF-7 cells were treated for 3 days with solvent vehicle (a), $40 \mu \mathrm{M}$ PBPE (b) or $10 \mu \mathrm{M} \mathrm{Tx}$ (c). The cells were stained with $300 \mathrm{nM}$ DAPI for 5 min and changes in nuclear morphology were observed by fluorescence microscopy. (E) Fragmentation of genomic DNA in adherent MCF-7 cells treated for $72 \mathrm{~h}$ with $40 \mu \mathrm{M}$ PBPE (lane 1), $40 \mu \mathrm{M}$ DPPE (lane 2) or $10 \mu \mathrm{M} \mathrm{Tx}$ (lane 3). (F) Effect of actinomycin D, cycloheximide, z-VAD-fmk and z-DEVD-fmk on the cytotoxicity induced by PBPE and Tx. MCF-7 cells were incubated for 3 days with $40 \mu \mathrm{M}$ PBPE or with $10 \mu \mathrm{M} \mathrm{Tx}$ in the absence or in the presence of $1 \mu \mathrm{g} / \mathrm{ml}$ actinomycin D (Act D), $2.5 \mu \mathrm{g} / \mathrm{ml}$ cycloheximide (CHX), $50 \mu \mathrm{M} z$-VAD-fmk or $50 \mu \mathrm{M}$ z-DEVD-fmk. Cell death was determined by Trypan blue exclusion test. Experiments were repeated at least three times in duplicate with comparable results. The data presented are the means \pm S.E. of three independent experiments. ${ }^{\star} P<0.0001$ compared with cells that received solvent vehicle

induced a full translocation of AIF from the mitochondria to the nucleus. Altogether, these data established that PBPE and Tx induced a robust alteration of the mitochondrial activity.

PBPE and Tx stimulated the production of ROS. We have reported in a preceding paper that AEBS ligands induced the appearance of oxysterols during cell-cycle control and the induction of differentiation characteristics in MCF-7 cells. ${ }^{9}$ The formation of oxysterols was inhibited by treatment of the cells with the antioxidant $\alpha$-tocopherol (vit E), suggesting the involvement of ROS in the stimulation of differentiation by
AEBS ligands. ${ }^{9}$ In this study, we examined whether PBPE and $\mathrm{Tx}$ increased the cellular level of oxidative stress in MCF-7 cells. To determine the production of ROS, we used a dihydroethidine probe (hydroethydium, HE), a substance that is oxidized by the superoxide anion to become ethydium bromide $(\mathrm{EthBr})$ that emits red fluorescence. ${ }^{12}$ We showed that 3 days treatment of MCF-7 cells with $40 \mu \mathrm{M}$ PBPE and $10 \mu \mathrm{M}$ Tx produced an increase in the red fluorescence, indicating a stimulation of the intracellular ROS (Figure 3a). We then evaluated the effect of antioxidants on cytotoxicity. We show that vit $E$ induced a full protection of cells, whereas 


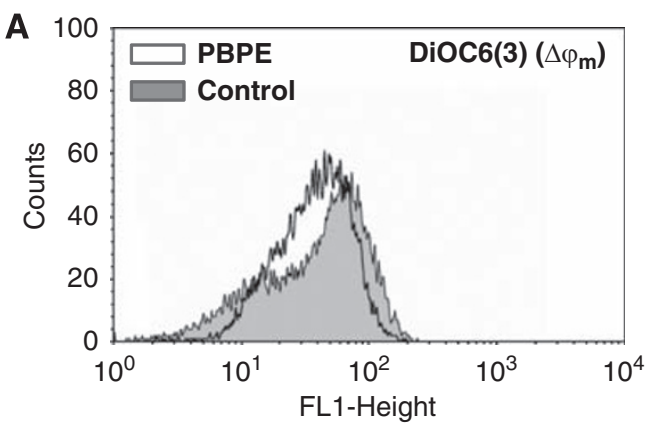

B

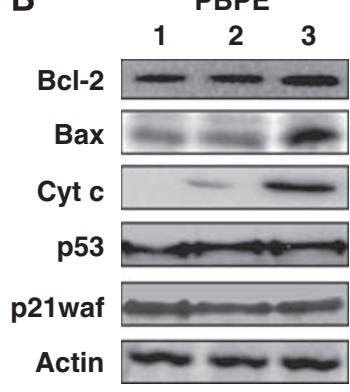

D

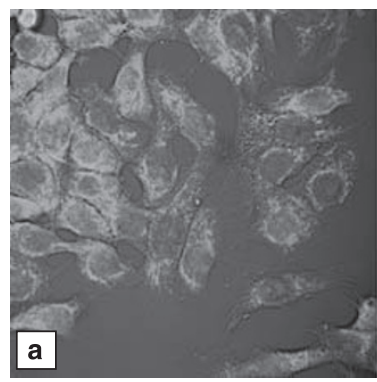

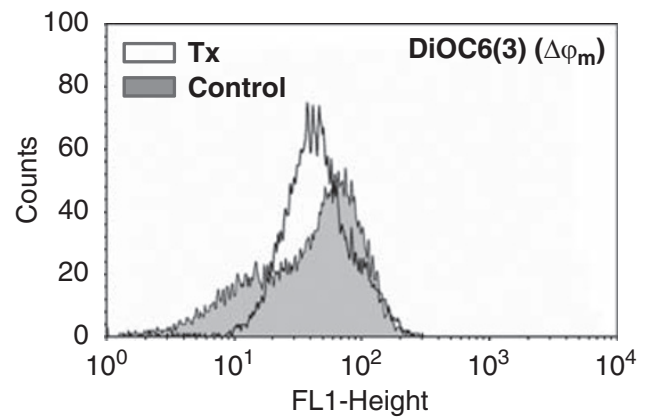

C
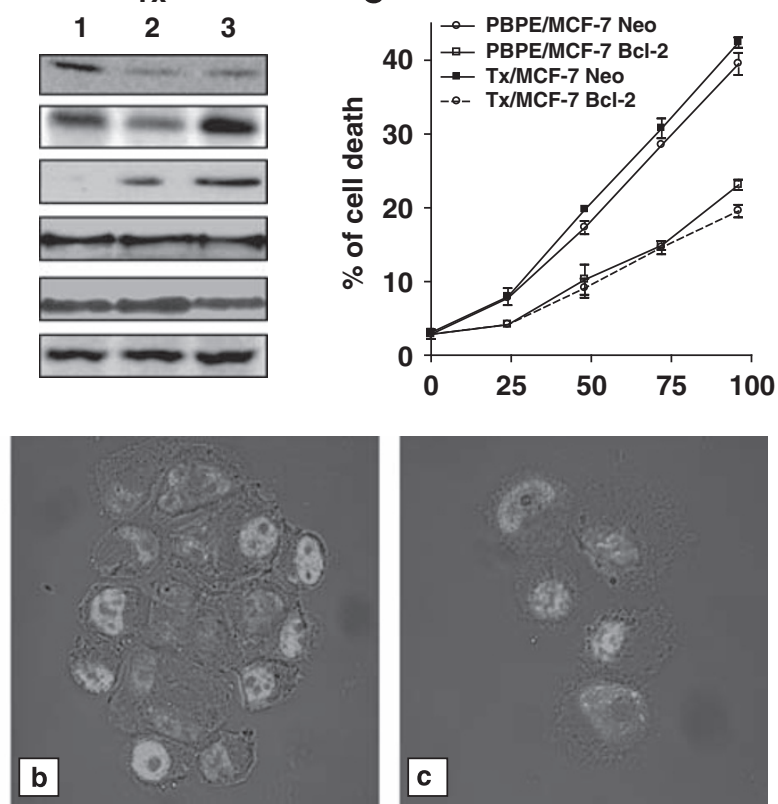

Figure 2 PBPE and Tx induced cytotoxicity through a mechanism that involved the mitochondria. (A) PBPE and Tx induced a modification of the $\triangle \psi_{\mathrm{m}}$ in MCF-7 cells. Cells were treated with EtOH, $40 \mu \mathrm{M} \mathrm{PBPE}$ or $10 \mu \mathrm{M} \mathrm{Tx}$ for $72 \mathrm{~h}$. After treatment, cells were stained with DiOC6(3) \pm CCCP and analyzed by flow cytometry as described in the Materials and Methods section. (B) Time course study of the effect of PBPE and Tx on the expression of Bcl-2, Bax, cytosolic cytochrome $c$ (Cyt $c$ ), p53, p21waf and actin levels in MCF-7 cells. Cells were treated with $40 \mu \mathrm{M}$ PBPE or with $10 \mu \mathrm{M}$ Tx for 3 days. Cells were collected and worked up as described in the Materials and Methods section. Proteins were subjected to SDS-PAGE and immunoblotted with antibodies against Bcl-2, Bax, Cyt c, p53, p21waf or actin. The images are representative from three independent experiments. (C) Determination of cell death on MCF-7/Bcl-2. MCF-7/Bcl-2 and MCF-7/Neo were treated $96 \mathrm{~h}$ with the solvent vehicle, $40 \mu \mathrm{M} \mathrm{PBPE}$ or $10 \mu \mathrm{M}$ Tx. Data were expressed as the percentage of cell death relative to total cells. Data were normalized to solvent vehicle-treated cells (taken to be $0 \%$ ). (D) Effect of PBPE and Tx on the nuclear translocation of AIF. MCF-7 cells were treated with the solvent vehicle (a), $40 \mu \mathrm{M}$ PBPE (b) or $10 \mu \mathrm{M}$ Tx (c) for $72 \mathrm{~h}$. AlF was detected by immunofluorescence staining as described in the Materials and Methods section. Experiments were repeated at least three times in duplicate with comparable results

other antioxidants, such as butylated hydroxytoluene (BHT) or $\mathrm{N}$-acetylcysteine (NAC), were inefficient (Figure $3 \mathrm{~b}$ ), showing the importance of the oxidation of lipophilic substances such as sterols in the mediation of the cytotoxicity. These data established that PBPE and Tx stimulate the production of ROS in MCF-7 cells at cytotoxic concentration and that the lipophilic antioxidant vit $\mathrm{E}$ induces a full cytoprotection against AEBS ligands.

PBPE and Tx induced macroautophagy in MCF-7 cells. Pioneering work by Bursch et $a l^{13}$ reported that $\mathrm{Tx}$ induced macroautophagy in MCF-7 cells, hence we evaluated whether the selective AEBS ligand, PBPE, induced macroautophagy in MCF-7 cells. The main characteristics of this process are the appearance of acidic vesicles stained with monodansylcadaverine (MDC) that are observable by fluorescence microscopy and the appearance of autophagic vesicles in the cytoplasm of cells observable by electron microscopy. ${ }^{13,14}$ In Figure 4A, we show that 3 days treatment of MCF-7 cells with $40 \mu \mathrm{M}$ PBPE (Figure $4 \mathrm{~A}(\mathrm{~b})$ ) or with $10 \mu \mathrm{M}$ Tx (Figure $4 \mathrm{~A}(\mathrm{c})$ ) caused a massive appearance of MDCpositive cytoplasmic vesicles. Ultrastructure analysis of cells by electron microscopy showed that PBPE (Figure 4B(a)) and Tx (Figure 4B(a)) produced morphological changes such as margination of chromatin, cell shrinkage and the formation of intracytoplasmic vesicles. We reported in an earlier study that AEBS ligands induced the appearance of intracytoplasmic unilamellar vesicules or lipid droplets (LDs), and showed that the appearance of LDs was due to the accumulation of triglyceride during the differentiation process induced by AEBS ligands. ${ }^{9}$ We also reported the presence of multilamellar bodies (MLBs) or of lysosomes that reflects the 

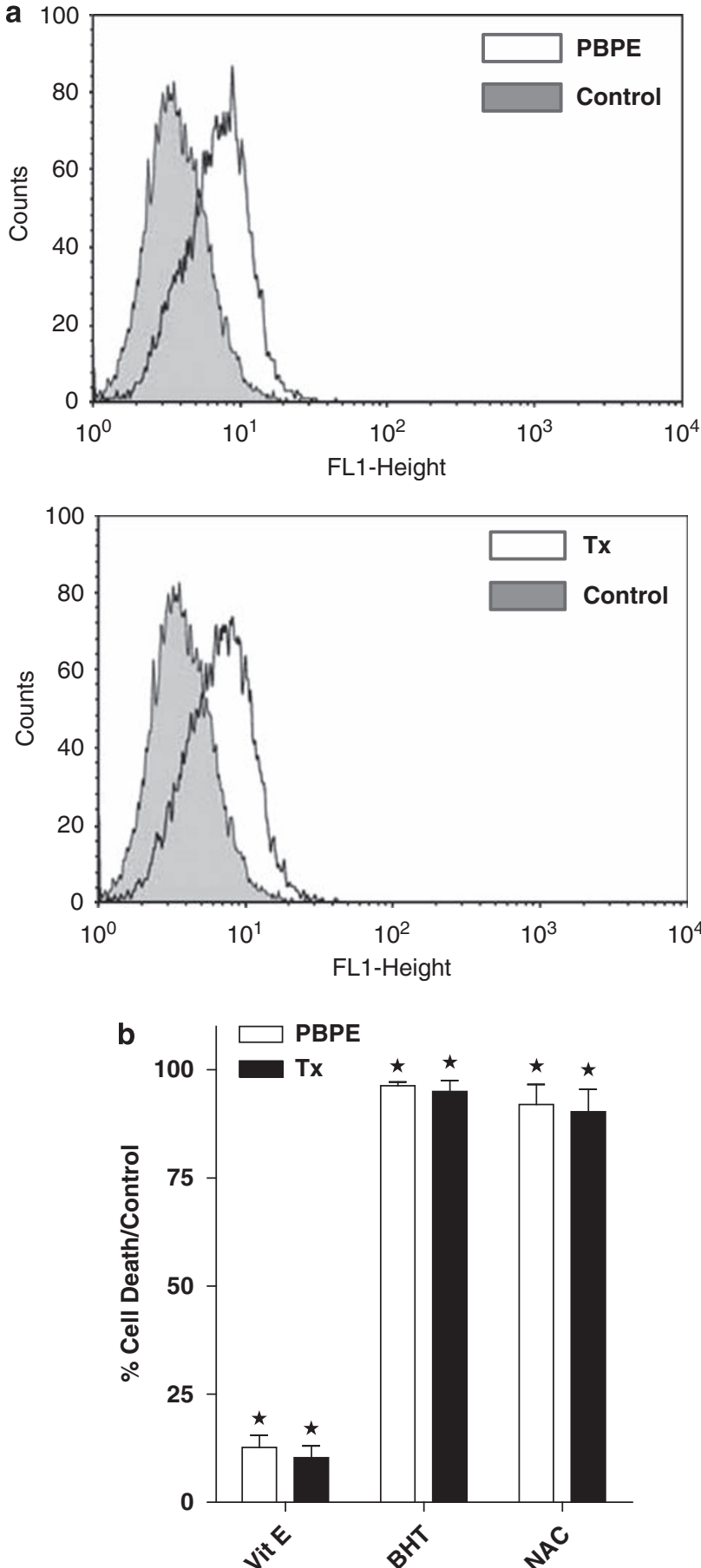

Figure $3 \mathrm{PBPE}$ and Tx induced the production of reactive oxygen species in MCF-7 cells. (a) PBPE and Tx increased the level of ROS in MCF-7 cells. MCF-7 cells were treated for $72 \mathrm{~h}$ with the solvent vehicle, $40 \mu \mathrm{M}$ PBPE or $10 \mu \mathrm{M} \mathrm{Tx}$. ROS production was determined by flow cytometry analysis on cells stained with dihydroethidine probe $(2.5 \mu \mathrm{M})$ as described in the Materials and Methods section. (b) Effect of antioxidant on the cytotoxicity induced by $40 \mu \mathrm{M}$ PBPE and $10 \mu \mathrm{M} \mathrm{Tx}$. MCF-7 cells were preincubated with vitamin $\mathrm{E}, \mathrm{BHT}$ or $\mathrm{N}$-acetylcysteine and then challenged with AEBS ligands for $72 \mathrm{~h}$. Cell death was determined by Trypan blue exclusion test. Data were expressed as the percentage of cell death relative to control cells that received $40 \mu \mathrm{M}$ PBPE or $10 \mu \mathrm{M} \mathrm{Tx}$. Experiments were repeated at least three times in duplicate with comparable results. The data presented are the means \pm S.E. of all experiments. ${ }^{\star} P<0.0001$ compared with control cells two-fold increased mass of unesterified (free) sterols in MCF-7 cells. We established that this accumulation of cholesterol precursors (mainly $5 \alpha$-cholest-8-en- $3 \beta$-ol (zymostenol)) was the consequence of the inhibition of cholesterogenic enzymes through binding of PBPE and Tx to the AEBS. ${ }^{2,9}$ The accumulation of free sterols was further established in Figure $7 \mathrm{a}$, showing that treatment of cells with PBPE and Tx induced the binding of filipin on perinuclear vesicles. Electron microscopic ultrastructure analysis of MCF-7 cells treated with PBPE or Tx led to the appearance of autophagosomes (Figure $4 \mathrm{~B}(\mathrm{c})$ ) and autolysosomes (Figure $4 \mathrm{~B}(\mathrm{~d})$ ). Autophagosomes were recognized by the presence of a double membrane surrounding cytoplasmic inclusions (Figure 4B(c)). We next studied the impact of PBPE and Tx on the expression of the autophagic proteins, Beclin-1 and LC3, by western blotting. Figure 4C shows that $40 \mu \mathrm{M}$ PBPE and $10 \mu \mathrm{M}$ Tx stimulated the expression of Beclin-1. The LC3 protein is known to undergo proteolysis, given a $16-\mathrm{kDa}$ fragment named LC3-II that is involved in autophagosome formation. ${ }^{15}$ We showed by western blot that PBPE and Tx increased the LC3-II 16-kDa fragment of LC3-I, which became the major fragment of the LC3 protein, compared with solvent vehicle-treated cells. Using a GFPLC3 construct, we showed that PBPE and Tx induced a 34 and $37 \%$ increase in the punctate GFP-LC3 staining, respectively, indicative of the relocalization of LC3 into vesicles (Figure 4C) and sustaining the view that the $16-\mathrm{kDa}$ proteolytic fragment may participate in the formation of autophagosomes. Moreover, PBPE and Tx stimulated the rate of long-lived protein degradation (Figure 4D), confirming the induction of the autophagic process by PBPE and Tx.

We next evaluated the potency of AEBS ligands to stimulate autophagic flux, which reflects more accurately the autophagic activity. ${ }^{15}$ Cells were pre-treated with lysosomal protease inhibitors (E64 (2S,3S)-trans-epoxysuccinyl-Lleucylamido-3-methylbutane ethyl ester) and pepstatin $A$ (Pep A), which inhibit the autophagic flux. ${ }^{16}$ This treatment increased the number of punctuate GFP-LC3 (Figure 5a) and induced an increase in the accumulation of LC3-II (Figure 5b). These data established that the AEBS ligands, PBPE and Tx, induced autophagic features in MCF-7 cells.

AEBS ligands belonging to different structural classes induced cell death with characteristics of autophagy in MCF-7 cells. Given that PBPE and Tx induced active cell death and autophagy in MCF-7 cells, we evaluated whether active MCF-7 cell death can be attributed to all AEBS ligands. We tested various AEBS ligands belonging to different substructural classes, having reported earlier that these compounds were high-affinity AEBS ligands and were potent inducers of MCF-7 cell differentiation. ${ }^{9}$ PBPE is a lead compound of the diphenylmethane series, ${ }^{4}$ and Table 1 showed that other members of this series, such as MBPE and tesmilifene (DPPE), induced similar effects showing that high-affinity and selective AEBS ligands are potent inducers of active cell death and macroautophagy in MCF-7 cells. Next, we established that dual modulators of the estrogen receptors and high-affinity AEBS ligands, such as clomiphene, $\mathrm{Cl}-628$, raloxifene, 4-hydroxytamoxifen $(4 \mathrm{OHTx})$ and $\mathrm{RU}$ 39,411 , induced similar effects than Tx. These compounds 
A

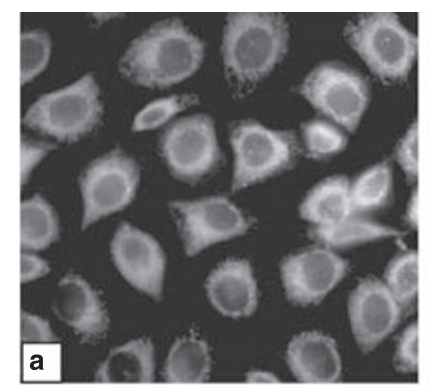

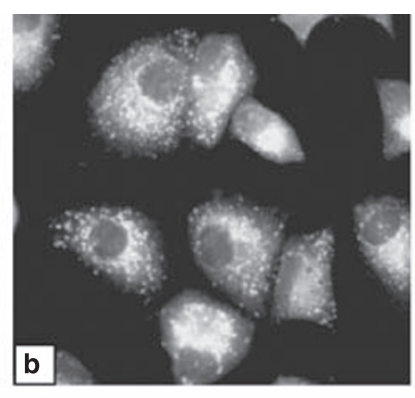

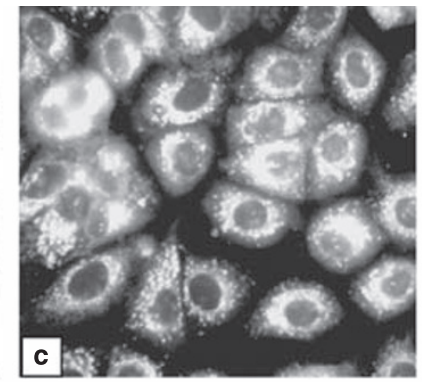

B
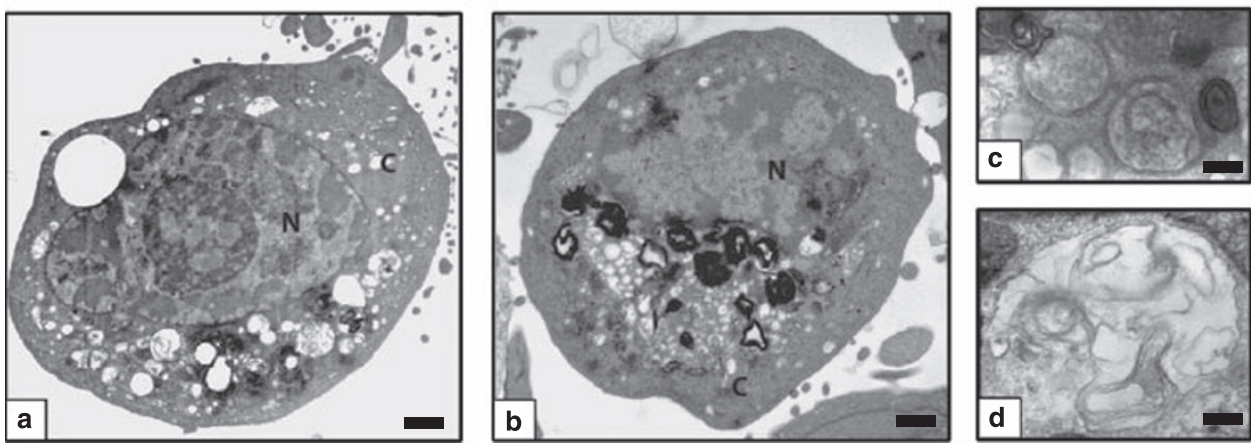

C

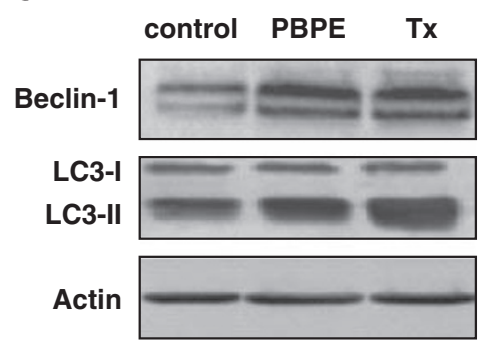

Figure 4 PBPE and Tx induced the appearance of the characteristics of macroautophagy. (A) Detection of monodansylcadaverine-positive vesicles. MCF-7 cells were treated with the solvent vehicle (a), $40 \mu \mathrm{M} \mathrm{PBPE}$ (b) or $10 \mu \mathrm{M} \mathrm{Tx}$ (c) for $72 \mathrm{~h}$ and stained as described in the Materials and Methods section. (B) Ultrastructural analysis of the effect of PBPE and Tx on MCF-7 cells. Cells were treated with $40 \mu \mathrm{M}$ PBPE (panels a, $\mathrm{C}$ and d) or with $10 \mu \mathrm{M} \mathrm{Tx}$ (panel b). N, nucleus; C, cytoplasm. Bars: $4 \mu \mathrm{m}$ for panels a and b, $400 \mathrm{~nm}$ for panel $c$ and $220 \mathrm{~nm}$ for panel d. (C) Effect of PBPE and Tx on the expression of the autophagic protein Beclin-1 and proteolysis of LC3. MCF-7 cells were treated with the solvent vehicle (control), $40 \mu \mathrm{M}$ PBPE or $10 \mu \mathrm{M}$ Tx for $72 \mathrm{~h}$. Cells were collected and their proteins were analyzed by western blotting. (D) Degradation of long time proteins was determined in MCF-7 cells treated with solvent vehicle, $40 \mu \mathrm{M}$ PBPE or $10 \mu \mathrm{M} \mathrm{Tx}$ for $18 \mathrm{~h}$ in the presence or in the absence of $10 \mathrm{mM}$ 3-MA. Experiments were repeated at least three times in duplicate with comparable results. The data presented are the means \pm S.E. of all experiments. ${ }^{\star} P<0.0001$ compared with control cells

induced the accumulation of different species of cholesterol precursors in MCF-7 cells. We have established earlier that clomiphene, $\mathrm{Cl}-628$ and $\mathrm{Tx}$ induced the accumulation of zymostenol, ${ }^{2}$ whereas raloxifene induced the accumulation of $5 \alpha$-cholest-8,24-dien-3 $\beta$-ol (zymosterol) and $4 \mathrm{OHTx}$ and RU 39,411 induced the accumulation of $5 \alpha$-cholest-5,24-dien$3 \beta$-ol (desmosterol). ${ }^{2}$ All these drugs are cationic amphiphilic drugs (CADs). Finally, we showed that neutral compounds of the oxysterols that bind to the AEBS were also potent inductors of active cell death with autophagic characteristics. These compounds induced the accumulation of zymostenol as observed with $\mathrm{Tx}^{2}$ These results showed that both CAD and neutral drugs induced an active cell death and macroautophagy, indicating that the physicochemical properties of these drugs were less important than their high-affinity interaction with the AEBS. These data show that high-affinity
AEBS ligands induced active cell death and macroautophagy in MCF-7 cells.

Inhibition of macroautophagy enhanced the cytotoxicity of PBPE and Tx, whereas inhibition of MCF-7 cell differentiation and death by vit $E$ did not affect macroautophagy. We next evaluated the consequence of the inhibition of the macroautophagy stimulated by the selective AEBS ligand, PBPE and Tx, in MCF-7 cells using pharmacological agents and by invalidating the expression of the autophagic protein ATG6/Beclin-1 gene. Pretreatment of cells with the class III PI3 kinase inhibitor, 3-methyladenine (3-MA), the inhibitor of $\mathrm{H}+$ ATPase, bafilomycin A1 (Baf A1), as well as knockdown of Beclin-1 protein inhibited the appearance of acidic vesicles positive to MDC in MCF-7 cells treated by PBPE and Tx, whereas vit $E$ had only a 
a

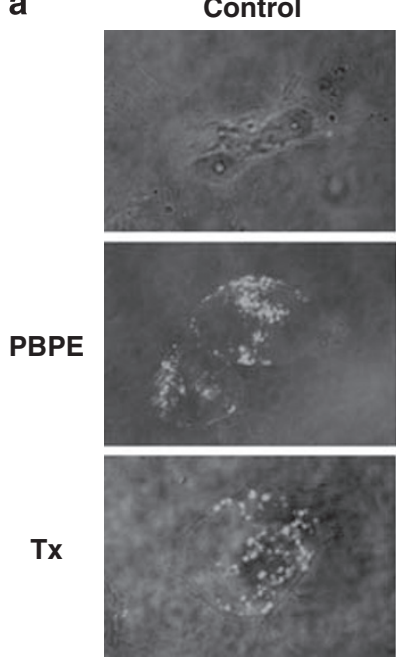

b

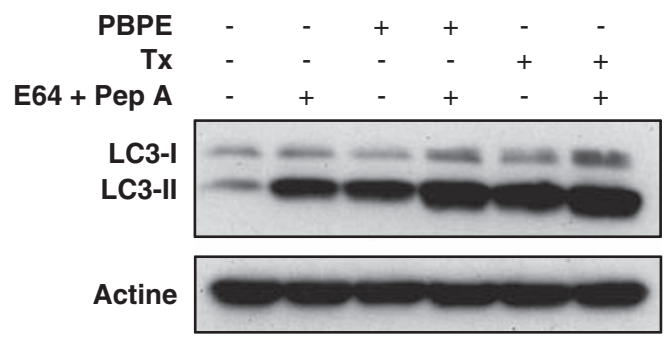

E64+ Pep A
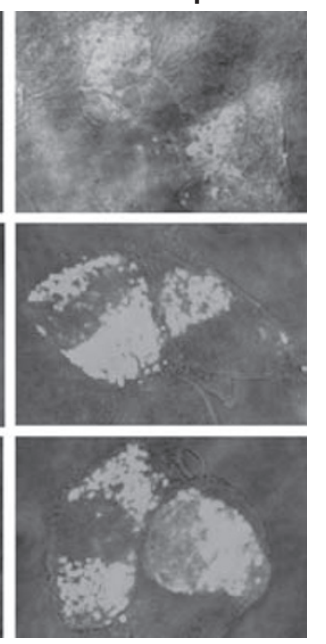
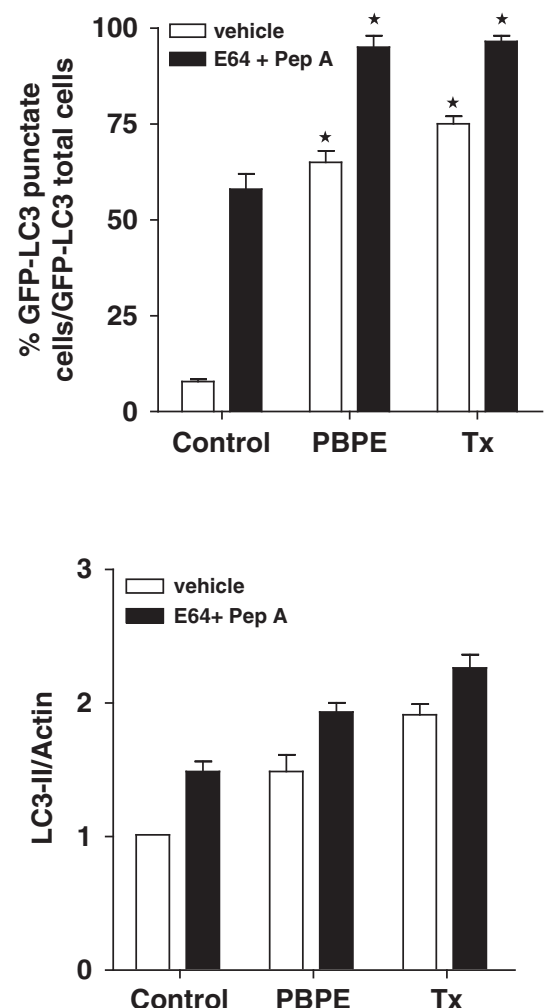

Figure 5 Effect of PBPE and Tx on the relocalization of GFP-LC3 on MCF-7 cells. (a) MCF-7 cells were transiently transfected with a plasmid expressing GFP-LC3 and subsequently treated after $24 \mathrm{~h}$ with the solvent vehicle, $40 \mu \mathrm{M}$ PBPE or $10 \mu \mathrm{M} \mathrm{Tx}$ for $72 \mathrm{~h}$ with or without pretreatment with lysosomal protease inhibitors, E64 + Pep A $10 \mu \mathrm{g} /$ $\mathrm{ml}$. Images are representative of at least three independent experiments. Quantitative analysis of GFP-LC3 cells. The percentage of GFP-positive cells with GFP-LC3 puncta was calculated. The results are expressed as mean \pm S.E. from at least three independent experiments. (b) Levels of LC3-II and $\beta$-actin proteins were analyzed by western blotting. Each picture shows one representative experiment out of three independent experiments. The ratio of LC3-II to actin levels in each experiment was determined densitometrically and normalized to vehicle values (taken to be 1). The values were expressed as the mean \pm S.E. of three independent experiments. ${ }^{\star} P<0.0001$ compared with control cells

Table 1 Evaluation of AEBS ligands on their potency to induce active cell death

\begin{tabular}{|c|c|c|c|c|c|c|c|}
\hline & $\begin{array}{l}\text { [Drug] } \\
\text { in } \mu \mathrm{M}\end{array}$ & $\begin{array}{c}\text { Annexin } \mathrm{V}^{+} / \mathrm{PI}^{-} \\
\text {cells in } \%\end{array}$ & $\begin{array}{l}\text { Bax induction } \\
>\times 4\end{array}$ & $\Delta \Psi_{\mathrm{m}}$ & ROS & $\begin{array}{l}\text { Fold increase } \\
\text { in Beclin }\end{array}$ & $\begin{array}{l}\text { Sterol } \\
\text { accumulated }\end{array}$ \\
\hline Control & - & - & - & - & - & - & - \\
\hline PBPE & 40 & 38 & + & Depol. & + & 3.6 & zymostenol \\
\hline DPPE & 40 & 40 & + & Depol. & + & 3.4 & zymostenol \\
\hline MBPE & 40 & 35 & + & Depol. & + & 2.8 & zymostenol \\
\hline $\mathrm{Tx}$ & 10 & 34 & + & Depol. & + & 3.2 & zymostenol \\
\hline $4 \mathrm{OHTx}$ & 10 & 32 & + & Depol. & + & 2.8 & desmosterol \\
\hline RU 39,411 & 10 & 36 & + & Depol & + & 2.8 & desmosterol \\
\hline Raloxifene & 10 & 36 & + & Depol. & + & 3.0 & zymosterol \\
\hline Cl-628 & 10 & 42 & + & Depol. & + & 3.1 & zymostenol \\
\hline Clomiphene & 10 & 42 & + & Depol. & + & 3.5 & zymostenol \\
\hline 7-Ketocholesterol & 40 & 28 & + & Depol. & + & 2.8 & zymostenol \\
\hline $7 \beta$-Hydroxycholesterol & 40 & 14 & + & Depol. & + & 2.1 & zymostenol \\
\hline 7-Ketocholestanol & 40 & 32 & + & Depol. & + & 3.2 & zymostenol \\
\hline
\end{tabular}

AEBS, antiestrogen-binding site; Depol, depolarization; DPPE, N,N-diethylamino-(phenylmethylphenoxy-ethanamine,HCl; 4OHTx, 4-hydroxytamoxifen; PBPE, $\mathrm{N}$-pyrrolidino-(phenylmethyphenoxy)-ethanamine, $\mathrm{HCl}$; PI, propidium iodide; ROS correspond to a stimulation of the production of reactive oxygen species; Tx, tamoxifen. MCF-7 cells were treated with the indicated concentrations of compounds for $72 \mathrm{~h}$ and analyzed for the given parameter as described in the Materials and Methods section. For sterol analysis, 10 million MCF-7 cells were incubated with the indicated concentration of compounds and work up as described in the Materials and Methods section for sterol analysis. The results correspond to the average of three experiments. Annexin- ${ }^{+} / \mathrm{PI}^{-}$cells: Cells that bind Annexin $\mathrm{V}$ but not PI. 

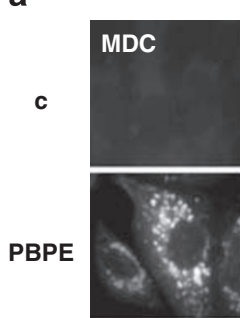

Tx
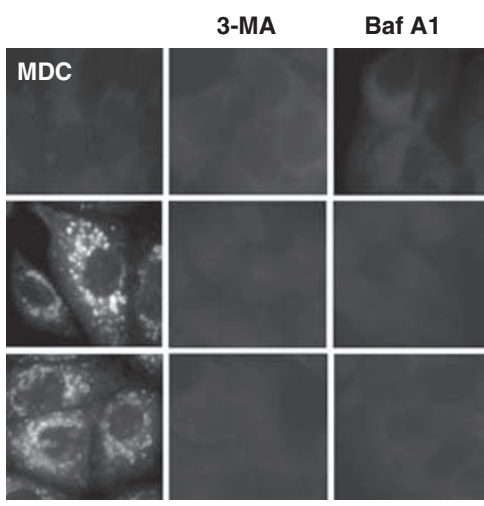

siBeclin 1
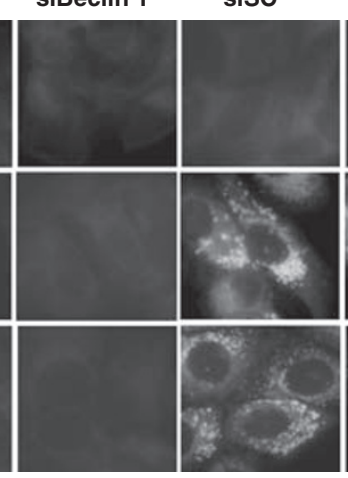

3-MA

Baf A1

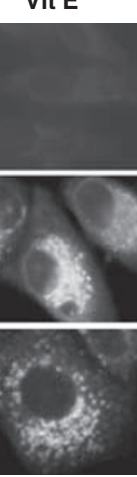

b
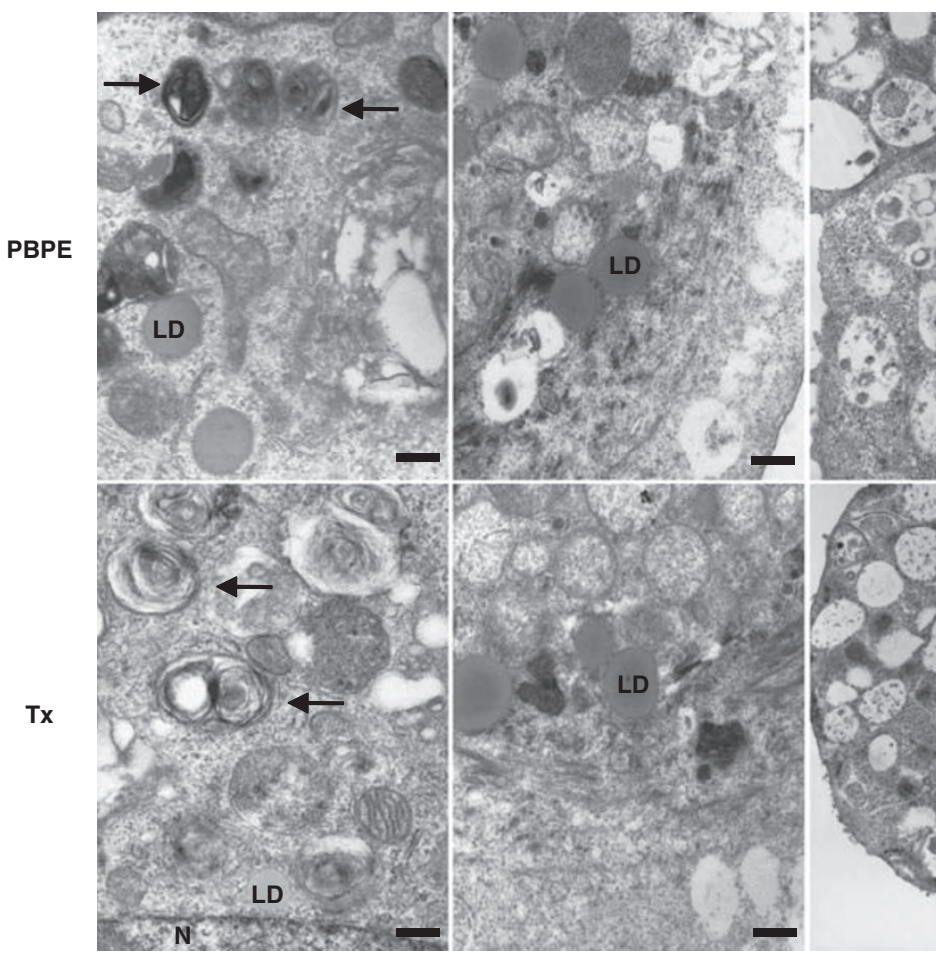

Baf A1
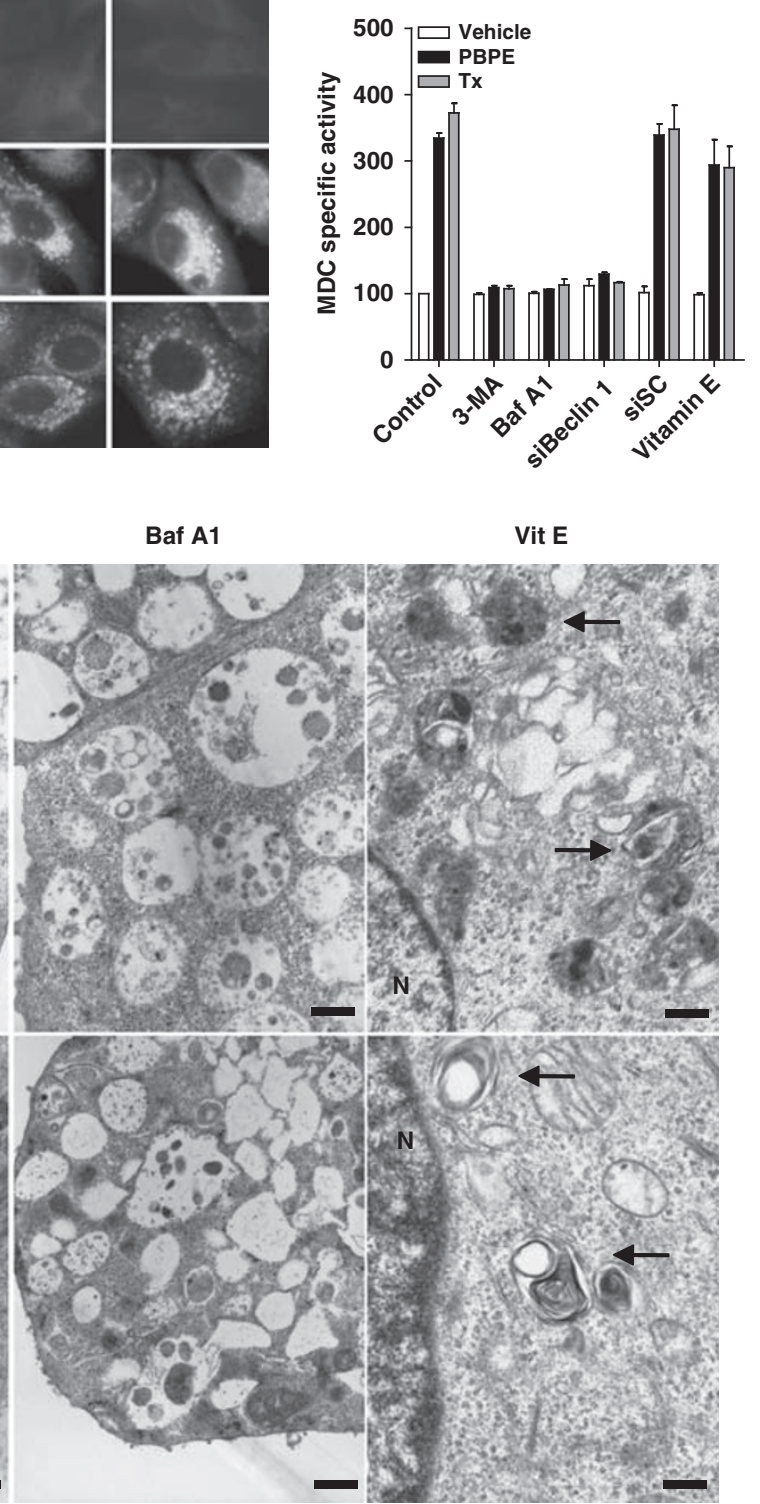

Figure 6 Inhibitors of autophagy but not of vitamin E blocked the accumulation of MDC-labeled vacuoles in MCF-7 cells treated with PBPE or Tx. MCF-7 cells were treated with the solvent vehicle (c), $40 \mu \mathrm{M}$ PBPE or $10 \mu \mathrm{M}$ Tx for $72 \mathrm{~h}$ with or without pretreatment with $10 \mathrm{mM} 3-\mathrm{MA}, 50 \mathrm{nM}$ Baf $\mathrm{A} 1$ or $500 \mu \mathrm{M}$ vitamin $\mathrm{E}$ (a). MCF-7 cells were transfected with scramble siRNA (siSC) or Beclin-1 (siBCN1) siRNA for $48 \mathrm{~h}$ and then treated with the solvent vehicle (c), $40 \mu \mathrm{M}$ PBPE or $10 \mu \mathrm{M}$ Tx for $72 \mathrm{~h}$. Cells were incubated with $0.05 \mathrm{mM} \mathrm{MDC}$ for $60 \mathrm{~min}$ at $37^{\circ} \mathrm{C}$ followed by fixation in $4 \%$ formaldehyde $(15 \mathrm{~min})$ and then washed twice with PBS. Cells were analyzed by fluorescence microscopy as described in the Materials and Methods section. Intracellular MDC was measured by fluorescence photometry as indicated in the Materials and Methods section. The data presented are the means \pm S.E. of three independent experiments. (b) Electron microscopic analysis of MCF-7 cells treated with solvent vehicle, $40 \mu \mathrm{M}$ PBPE or $10 \mu \mathrm{M}$ Tx for 3 days in the presence or in the absence of $10 \mathrm{mM} 3-\mathrm{MA}, 50 \mathrm{nM}$ Baf $\mathrm{A} 1$ or $500 \mu \mathrm{M}$ vitamin $\mathrm{E}$. Original magnification $\times 10000$. LD, lipid droplets; $\mathrm{N}$, nucleus; arrows indicate multilamellar intracytoplasmic vesicles. Bars $=0.5 \mu \mathrm{m}$. Experiments were repeated at least three times in duplicate with comparable results. The data presented are the means \pm S.E. of three independent experiments

marginal effect (Figure 6a). Ultrastructure analyses showed that despite a loss of MDC labeling, cells contained the same amount of vacuoles than cells treated with PBPE or Tx. We observed that LDs were still present but that MLBs were not detectable and other, less acidic vacuoles appeared (Figure 6b). Treatment with Baf A1 induced the disappearance of both sorts of vesicles to the profit of less acidic and bigger vesicles. These vesicles contained small MLB or amorphous content that evocated the presence of neutral lipids. This established that MLBs as well as LDs contain proton-ATPase sensitive to Baf A1. Co-treatment of cells with PBPE or Tx and with vit E eliminated LDs but MLBs were still present. These data established that inhibitors of autophagy and vit $E$ induced changes in the vesicular content of MCF-7 cells treated with PBPE or Tx. We next evaluated whether the induction of differentiation characteristics by PBPE and Tx was involved in the induction of macroautophagy. MCF-7 cell differentiation was mainly 
characterized by the accumulation of sterols that formed MLBs, which under oxidative stress induced the synthesis of triglycerides to generate LDs stained by Oil-Red O (ORO). ${ }^{9}$ Free sterol accumulation can be detected in cells by filipin binding. MCF-7 cells treated with $40 \mu \mathrm{M}$ PBPE and $10 \mu \mathrm{M}$ Tx accumulated filipin-positive vesicles that are not present on control cells. Both the inhibition of autophagy with 3-MA, Baf A1 or through the knockdown of Beclin-1 protein (confirmed a

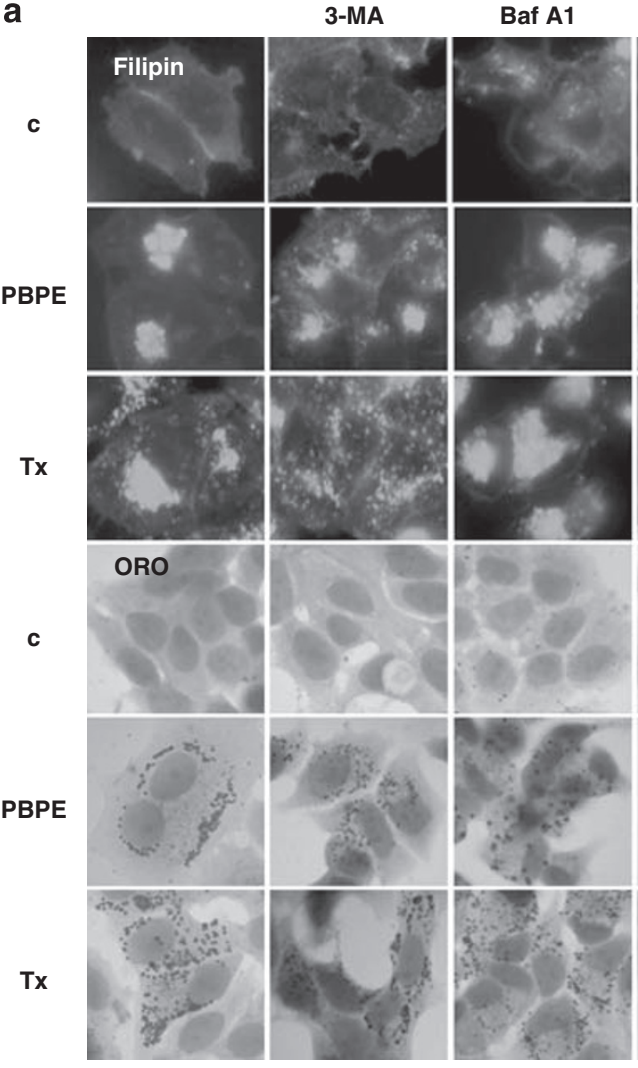

b
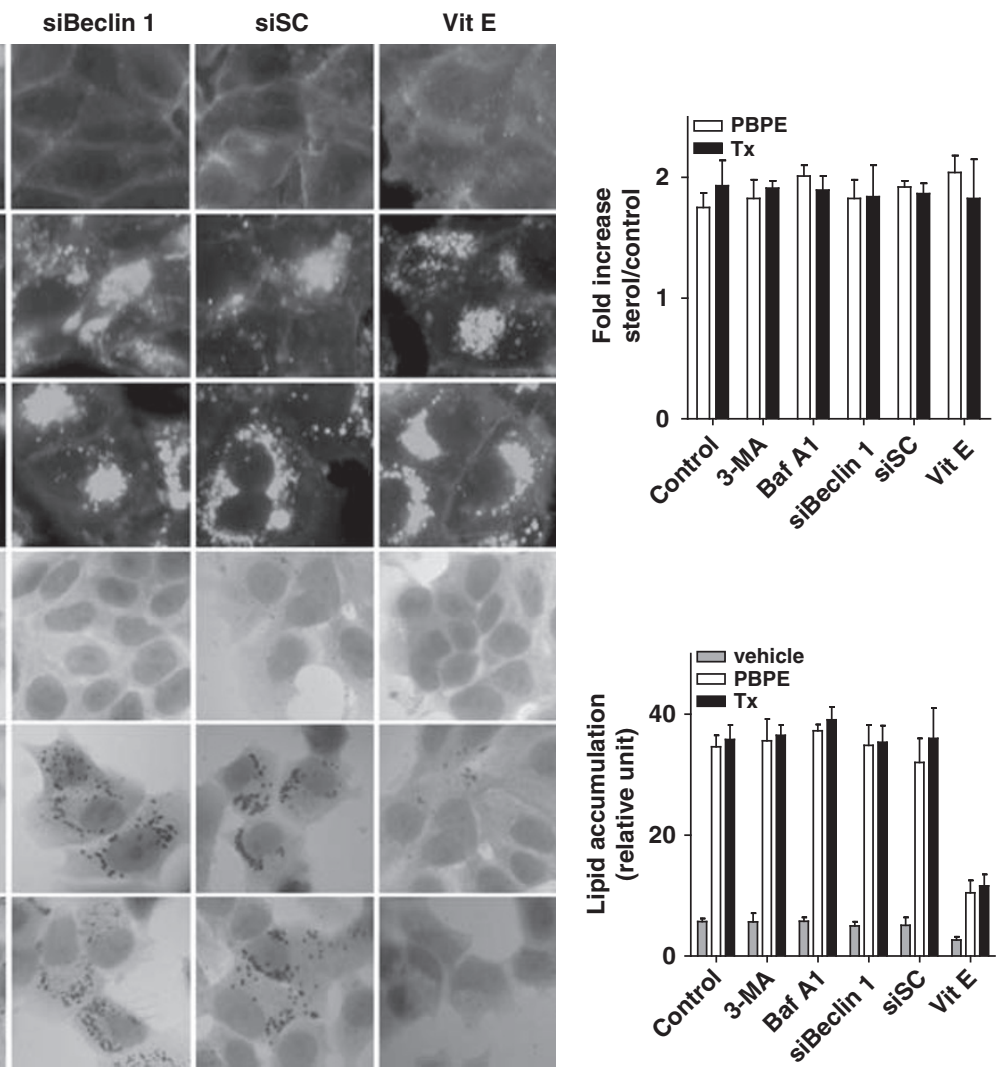

c
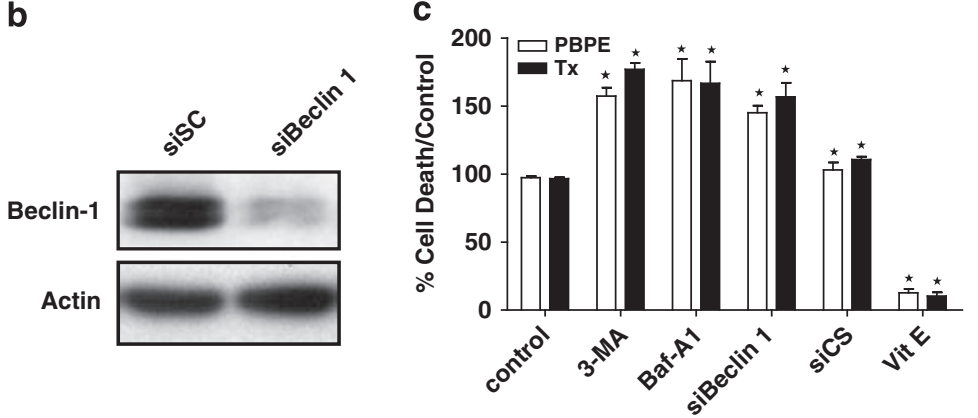

Figure 7 Effect of inhibitors of autophagy and vitamin $\mathrm{E}$ on the intracellular accumulation of free sterols and neutal lipids and cell death. (a) Free sterol and neutral lipid accumulation. MCF-7 cells were treated with the solvent vehicle (c), $40 \mu \mathrm{M} \mathrm{PBPE}$ or $10 \mu \mathrm{M} \mathrm{Tx}$ for $72 \mathrm{~h}$ with or without pretreatment with $10 \mathrm{mM} 3-\mathrm{MA}, 50 \mathrm{nM}$ Baf $\mathrm{A} 1$ or $500 \mu \mathrm{M}$ vitamin E. MCF-7 cells were transfected with scramble siRNA (siSC) or Beclin-1 (siBeclin 1) siRNA for $24 \mathrm{~h}$ and then treated with the solvent vehicle (c), $40 \mu \mathrm{M}$ PBPE or $10 \mu \mathrm{M}$ Tx for $72 \mathrm{~h}$, fixed with $3.7 \%$ paraformaldehyde for $15 \mathrm{~min}$ at room temperature followed by washing twice with PBS (Euromedex) and stained with filipin ( $50 \mu \mathrm{g} / \mathrm{ml}$ ) for $75 \mathrm{~min}$ at room temperature followed by washing twice with PBS. Cells containing free sterols are colored in blue. Quantification of free sterols was carried out as described in the Materials and Methods section. The data presented are the means \pm S.E. of three independent experiments. For neutral lipids analyses, cells were fixed with $3.7 \%$ paraformaldehyde for $1 \mathrm{~h}$ at room temperature followed by washing twice with PBS (Euromedex) and stained with Oil Red O (ORO) in 60\% (v/v) isopropyl alcohol, and hematoxylin. Quantitative analysis of lipid accumulation was carried out by extracting the ORO-stained cells with isopropyl alcohol and measuring the absorbance at $492 \mathrm{~nm}$ as described in the Materials and Methods section. The data presented are the means $\pm S$ S.E. of three independent experiments. (b) Effect of siRNA on Beclin-1 expression. MCF-7 cells were transfected with scramble siRNA (siSC) or with Beclin-1 (siBeclin 1) siRNA for $24 \mathrm{~h}$. The protein expression of Beclin 1 was monitored by western blot relative to $\beta$-actin (c) cell death. MCF-7 cells were treated with the solvent vehicle (c), $40 \mu \mathrm{M}$ PBPE or $10 \mu \mathrm{M}$ Tx for $72 \mathrm{~h}$ with or without pretreatment with $10 \mathrm{mM} 3-\mathrm{MA}, 50 \mathrm{nM}$ Baf A1 or $500 \mu \mathrm{M}$ vitamin E. MCF-7 cells were transfected with scramble siRNA (siSC) or Beclin-1 (siBeclin 1) siRNA for $24 \mathrm{~h}$ and then treated with the solvent vehicle (c), $40 \mu \mathrm{M}$ PBPE or $10 \mu \mathrm{M} \mathrm{Tx}$ for $72 \mathrm{~h}$. Data were expressed as the percentage of dead cells relative to cell death measured with single treatment with PBPE or Tx (taken to be $100 \%$ ). Experiments were repeated at least three times in duplicate with comparable results. The values were expressed as the mean $\pm S$.E. of three independent experiments. $\star P<0.0001$ compared with control cells 
in Figure 7b) and the treatment of cells with the antioxidant vit E did not block this process. Sterol analysis confirmed that the increase in the amount of free sterols in MCF-7 cells treated with PBPE or Tx remained unchanged (Figure 7a). This established that despite the modification of their morphology, vesicles examined by electron microscopy when cells are co-treated with PBPE or Tx and with 3-MA or Baf $A 1$ (Figure $6 b$ ) contained free sterols. ORO staining showed that inhibition of autophagy with 3-MA, Baf A1 or Beclin-1 knockdown did not inhibit lipogenesis (Figure 7a), whereas vit $E$ inhibited the formation of ORO-positive vesicles (Figure 7a). We next evaluated the impact to these inhibitors on cell death and showed that inhibition of macroautophagy led to an increase in cell death, whereas vit E protected cells against the cytotoxicity induced by PBPE and Tx (Figure 7c). Altogether, these data established that vit $E$ protects cells against death, inhibits the accumulation of LDs and has no impact on sterol accumulation (Figure 7a). Thus, in the case of MCF-7 cell treatment with PBPE and Tx, the accumulation of free sterols is common to autophagy and cell death. Sterol autoxidation, which is inhibited by vit $E,{ }^{9}$ is not required for the induction of autophagy, but is involved in the induction of cell differentiation and death. These data established that sterol accumulation by PBPE and Tx, which is a consequence of their binding to the AEBS, was necessary and sufficient to induce macroautophagy, whereas cytotoxicity required sterol accumulation and cell differentiation.

\section{Discussion}

We established earlier that PBPE or Tx induced cell-cycle arrest and lactation processes in human breast cancer cells and that higher concentrations of the drugs induced cell death. ${ }^{9}$ We established that this effect was due to the accumulation of cholesterol precursors and their autoxidation products. We report here that cytotoxic concentrations of PBPE $(40 \mu \mathrm{M})$ and $\mathrm{Tx}(10 \mu \mathrm{M})$ caused active cell death with the characteristics of macroautophagy in MCF-7 cells. First, both compounds induced an early apoptosis event by stimulating the presentation of phosphatidylserine at the outer leaflet of the cytoplasmic membrane, as shown by Annexin $\mathrm{V}$ binding at the cell surface. Second, PBPE and Tx induced condensation of the chromatin and DNA laddering, which are both characteristics of apoptosis. Active cell death was further established by showing that the expression of genes at the transcription and at the translation level was required because Act D (an inhibitor of gene transcription) and $\mathrm{CHX}$ (an inhibitor of mRNA translation) protected MCF-7 cells against the PBPE- and Tx-induced cytotoxicity.

PBPE and Tx depolarized the mitochondrial membrane as judged by the reduction in the $\Delta \Psi_{\mathrm{m}}$. We reported in an earlier paper that PBPE and Tx induced the quantitative intracellular accumulation of cholesterol precursors that are transformed into active autoxidation products. ${ }^{2,9}$ We have determined that these oxysterols are oxygenated on ring $B$ of the steroid backbone (M Poirot et al, unpublished results). This class of oxysterols has been reported to depolarize the mitochondrial membrane potential in cancer cells, ${ }^{17}$ showing the link between the accumulation of oxysterols in MCF-7 cells treated with AEBS ligands and the diminution of the $\Delta \Psi_{\mathrm{m}}$. Modifications of the mitochondria were further characterized by a significant modulation in the expression of the mitochondrial proteins Bcl-2 and Bax. PBPE and Tx changed the Bcl-2/Bax ratio in favor of the pro-apoptotic protein Bax. The stimulation of Bax expression is linked to the induction of the mitochondrial outer membrane permeability, ${ }^{18}$ which explains the release of cytochrome $c$ into the cytoplasm and the relocalization of AIF from the mitochondria to the nucleus that we observed with PBPE and Tx. These data established that PBPE and Tx produced a considerable alteration of the mitochondria linked to the production of oxysterols and established that the mitochondria is involved in cytotoxicity.

We showed that PBPE and Tx induced macroautophagy. This confirms an earlier report related to the induction of autophagy by $\mathrm{Tx}$, but established for the first time that this is the hallmark of AEBS ligands. Both PBPE and Tx induced the accumulation of sterols, ${ }^{9}$ which lead to the appearance of MLBs, and the stimulation of the expression of the autophagic protein Beclin-1. These features recapitulate the phenotype of Nieman-Pick type $\mathrm{C}$ disease, in which cells accumulate sterols in multilamellar bodies, and this was associated with the induction of macroautophagy. ${ }^{19,20}$

We observed that every tested high-affinity AEBS ligand was cytotoxic and induced macroautophagy in MCF-7 cells (Table 1). These effects occurred with both CADs, such as SERM, and neutral compounds, such as oxysterols, indicating that it was not related to their physicochemical properties but rather to their capacity to induce the accumulation of cholesterol precursors. Electron microscopy ultrastructure analysis showed that the frequency of autophagosomes was higher with $4 \mathrm{OHTx}$ and with RU 39,411 than with other AEBS ligands. Interestingly, we reported earlier that $4 \mathrm{OHTx}$ and $\mathrm{RU}$ 39,411 induced the accumulation of desmosterol, which does not accumulates when cells were treated with other AEBS ligands, suggesting that the accumulation of desmosterol may have a greater impact on the stimulation of macroautophagy than on zymostenol or zymosterol. It is established that cholesterol precursors differ in their capacity to modulate the plasticity of membranes and the formation of lipid rafts. ${ }^{21}$ On the other hand, the presence of a double bond at the C24 position on sterols such as desmosterol makes them direct activators of liver $X$ receptors (LXRs); ${ }^{22}$ they are ligandactivated transcription factors that regulate the expression of genes controlling lipid metabolism. Moreover, desmosterol was shown to stimulate cell proliferation and survival, ${ }^{23}$ whereas zymostenol and 7-dehydrocholesterol inhibit cell growth. ${ }^{9}$ Recently, the induction of macroautophagy by 4OHTx was reported and related to Tx resistance when used in association with $17 \beta$-estradiol in vitro. ${ }^{24}$ Desmosterol is the substrate of the desmosterol reductase (DHCR24, seladin-1), which catalyzes the transformation of desmosterol into cholesterol. DHCR24 was reported to be under the transcriptional control of the estrogen receptor, ${ }^{25}$ and to display a cytoprotection against oxidative stress. ${ }^{25-27}$ Long-term treatment of MCF-7 cells with 4OHTx may upregulate DHCR24 and scavenge sterol autoxidation, leading to a protection against cytotoxicity. The study of the involvement of DHCR24 or desmosterol in the processes leading to resistance to $\mathrm{Tx}$ and $4 \mathrm{OHTx}$ deserves further investigations. 
Recent studies reported that autophagy was involved in the physiological process of lactation during the step of involution and participated in the clearance of lactating cells. ${ }^{28} \mathrm{We}$ observed that in human breast cancer cells treated with AEBS ligands, the presentation of phosphatidyl serine was stimulated. It has been reported in the literature that PS presentation is involved in the phagocytosis of dying cells by macrophages. ${ }^{29}$ Thus, it will be of interest to determine whether this mechanism participates in the anticancer activity of PBPE and Tx in vivo.

Interestingly, the mechanism stimulated by AEBS ligands mimics at least part of the process of mammary gland remodeling during involution. ${ }^{30}$ For a long time, it has been established that breast feeding protects the breast against neoplastic transformation, ${ }^{31}$ and thus it can be hypothesized that the involution process is involved in this effect. Therefore, the induction of lactation, of active cell death and of macroautophagy in breast cancer cells through the modulation of cholesterol metabolism could be part of the anticancer and chemopreventive mechanism of action of Tx, in addition to estrogen receptors.

The therapeutic concentration of $\mathrm{Tx}$ has been determined to be between 1 and $10 \mu \mathrm{M}$ in the blood of treated patients, ${ }^{32}$ showing that the effects of Tx reported here are pharmacologically relevant.

These data established that the accumulation of cholesterol precursors through the inhibition of cholesterogenic enzymes that constitute or that are associated with the AEBS by PBPE or Tx are necessary and sufficient to induce macroautophagy in MCF-7 cells. These data further established that the accumulation of cholesterol precursors was necessary but not sufficient to induce cell death because ROS are required to produce oxysterols that trigger MCF-7 cell differentiation and death. The identification of these oxysterols deserves further studies. Altogether, our data show for the first time that selective AEBS ligands induced an active cell death with the characteristics of autophagy in breast cancer cells and stimulate events involved in the chemoprevention of cancers that support their therapeutic and prophylactic use.

\section{Materials and Methods \\ Chemicals and reagents. PBPE and DPPE were synthesized as described earlier. ${ }^{4}$ Caspase inhibitors z-VAD-fmk and z-DEVD-fmk were from Calbiochem. 7-Ketocholestanol was from Steraloids. RU 39,411 was from Sanofi-Aventis. Cl-628 was from Park Davis. Baf A1, Pep A, E64, 3-MA, MDC, Tx, 4OHTx, clomiphene, filipin and oxysterols were from Sigma-Aldrich.}

Cell lines and cell culture. MCF-7 cells were from the American Type Culture Collection (ATCC) and cultured until passage 30. MCF-7 cells were grown in the RPMI 1640 medium supplemented with $1.2 \mathrm{mM}$ glutamine $\left(\mathrm{pH} 7.4\right.$ at $\left.23^{\circ} \mathrm{C}\right), 5 \%$ fetal bovine serum (FBS), penicillin and streptomycin $(50 \mathrm{U} / \mathrm{ml})$ in a humidified atmosphere with $5 \% \mathrm{CO}_{2}$ at $37^{\circ} \mathrm{C}$. MCF-7/bcl-2 expressed a 50 -fold higher level of $\mathrm{Bcl}-2$ protein than that of the parental cell line transfected with the control vector (MCF-7/neo). ${ }^{33}$ These cells were a kind gift from Dr A. Valette (Toulouse).

Cell death assays. Cells were seeded in RPMI with $5 \%$ FBS into 12-well plates at 30000 cells per well. The cells were then treated with solvent vehicle $(0.1 \%$ ethanol), $40 \mu \mathrm{M}$ PBPE or $10 \mu \mathrm{M}$ Tx for 3 days. Treated cells were incubated in the

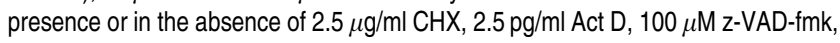
$100 \mu \mathrm{M}$ z-DEVD-fmk, $500 \mu \mathrm{M}$ vit E, $1 \mathrm{mM} \mathrm{NAC}, 500 \mu \mathrm{M}$ BHT, $10 \mathrm{mM}$ 3-MA or $50 \mathrm{nM}$ Baf A1. Cell death was determined by the Trypan blue exclusion assay. The cells were scraped and resuspended in the Trypan blue solution $(0.25 \%(\mathrm{w} / \mathrm{v})$ in PBS) and counted in a Malassez cell under a light microscope.

Clonogenic assay. MCF-7 cells were trypsinized and plated in $60 \mathrm{~mm}$ tissue culture plates at a density of 500-1000 per plate. Cells were allowed to adhere for $24 \mathrm{~h}$, and drugs were added as indicated to the final concentrations from 1,000-fold concentrated stocks. After 24 to $72 \mathrm{~h}$ incubation, the plates were washed twice with serum-free medium, fresh medium was added and the cells were incubated until colonies were visible. The plates were washed once with PBS and stained with Coomassie brilliant blue. Visible colonies were counted and reported as the percentage of control cells (ethanol-treated, $0,01 \%(v / v)$ ).

Annexin V and PI staining. Double staining for Annexin V-FITC binding and DNA using PI was carried out on MCF-7 cells exposed to ethanol, to $40 \mu \mathrm{M}$ PBPE or to $10 \mu \mathrm{M} \mathrm{Tx}$ up to 3 days. Cells were washed in PBS and resuspended in the binding buffer ( $10 \mathrm{mM}$ HEPES, $140 \mathrm{mM} \mathrm{NaCl}, 2.5 \mathrm{mM} \mathrm{CaCl}, 0.1 \%$ bovine serum albumin, $\mathrm{pH}$ 7.4). The cell suspension was incubated with Annexin-V-FITC (Southern Biotech, Birmingham, AL, USA) on ice. After $15 \mathrm{~min}$, an additional $380 \mu \mathrm{l}$ of the binding buffer was added, followed by $0.5 \mathrm{mg} / \mathrm{ml} \mathrm{PI}$ immediately before the analysis on a BD Facscalibur flow cytometer (BD Biosciences, San Diego, CA, USA). The percentage of Annexin V-FITC/propidium iodide-positive cells was determined using CellQuest software (BD Biosciences).

Assessment of apoptosis morphology by DAPI. After treatment with or without $40 \mu \mathrm{M}$ PBPE or $10 \mu \mathrm{M}$ Tx for $72 \mathrm{~h}$, both floating cells and trypsinized adherent cells were collected, washed once with ice-cold PBS, fixed with $1 \mathrm{ml}$ of $4 \%$ paraformaldehyde for $20 \mathrm{~min}$, and washed once with ice-cold PBS. Then the cells were incubated with $1 \mathrm{ml} \mathrm{PBS}$ containing $300 \mathrm{nmol} / \mathrm{L}$ DAPI (Roche, Indianapolis, IN, USA) at $37^{\circ} \mathrm{C}$ for $30 \mathrm{~min}$, washed twice and observed using fluorescence microscopy.

DNA fragmentation analysis by gel electrophoresis. After treatment with the drugs, the cells were lysed in the buffer containing $10 \mathrm{mM}$ Tris- $\mathrm{HCl}, \mathrm{pH} 7.4$, $10 \mathrm{mM}$ EDTA, $10 \mathrm{mM} \mathrm{NaCl}, 0.5 \%$ SDS and $0.5 \mathrm{mg} / \mathrm{ml}$ proteinase $\mathrm{K}\left(40 \mu \mathrm{l}\right.$ per $10^{6}$ cells) overnight at $48^{\circ} \mathrm{C}$. RNase $A$ was then added to the mixture adjusted to $5 \mathrm{mg} /$ $\mathrm{ml}$ and incubated for $3 \mathrm{~h}$ at $50^{\circ} \mathrm{C}$. The DNA was isolated using phenol/chloroform extraction and ethanol precipitation. Pellets were air-dried and suspended in $50 \mu \mathrm{l}$ Tris-EDTA buffer. DNA samples $(10 \mu \mathrm{g})$ were prepared in a neutral loading buffer ( $0.25 \%$ bromophenol blue, $0.25 \%$ xylene cyanol and $30 \%$ glycerol in Tris-EDTA buffer), and run on a $1.2 \%$ agarose gel and stained with ethidium bromide.

Western blotting. Immunoblotting was carried out as described earlier. ${ }^{2}$ Proteins were separated on a $12.5 \%$ SDS-PAGE gels, electro-transferred onto polyvinylidene difluoride membranes and incubated overnight at $4{ }^{\circ} \mathrm{C}$ with the mouse anti-human anti-Bcl-2, anti-Bax (Chemicon International, Temecula, CA, USA), anti-Beclin-1, anti-LC3, anti-P53, anti-P21 or anti-Actin (Santa Cruz Biotechnology, Santa Cruz, CA, USA). For cytochrome $c$ analyses, the cytosolic extracts were prepared by lyses by freeze-thaw the cell pellet in the HEPES buffer (20 mM HEPES-KOH, pH 7.5, $10 \mathrm{mM} \mathrm{KCl}, 1.5 \mathrm{mM} \mathrm{MgCl} 2,1 \mathrm{mM}$ EDTA-Na, $1 \mathrm{mM}$ EGTA-Na, $1 \mathrm{mM}$ dithiothreitol and a cocktail of protease inhibitors). The cell extracts were first centrifuged for $10 \mathrm{~min}$ at $1000 \times g$ at $4^{\circ} \mathrm{C}$. The resulting supernatant was spun at $10000 \times \mathrm{g}$ at $4^{\circ} \mathrm{C}$ for $10 \mathrm{~min}$, and the supernatant obtained was centrifuged for $1 \mathrm{~h}$ at $105000 \times \mathrm{g}$ at $4^{\circ} \mathrm{C}$ to obtain a cytosol fraction. Proteins were separated on $10 \%$ SDS-PAGE, electro-transferred onto polyvinylidene difluoride membranes and incubated overnight at $4^{\circ} \mathrm{C}$ with a mouse anti-human cytochrome $c$ (Pharmingen). Visualization was achieved using an ECL plus kit (Amersham Biosciences), and fluorescence was measured either by autoradiography or using a phosphor imager (Storm 840, Amersham Biosciences).

Cytofluorometric analysis. To measure the $\Delta \Psi_{\mathrm{m}}$, cells were incubated at $37^{\circ} \mathrm{C}$ for $15 \mathrm{~min}$ in the presence of $40 \mathrm{nM}$ DiOC6(3) (Molecular Probes) with or without $100 \mu \mathrm{M}$ carbonyl cyanide $m$-chlorophenylhydrazone (CCCP). To determine superoxide anion generation, cells were kept at $37^{\circ} \mathrm{C}$ for $15 \mathrm{~min}$ in the presence of $10 \mu \mathrm{M} \mathrm{HE}$ (Molecular Probes). After incubation with DiOC6(3) or HE, the cells were immediately analyzed by flow cytometry on a BD Facscalibur flow cytometer (BD Biosciences). DiOC6(3) was excited at $488 \mathrm{~nm}$ and detected at $525 \mathrm{~nm}$. HE was excited at $490 \mathrm{~nm}$ and detected at $620 \mathrm{~nm}$. 
AEBS binding assay. Binding assays were performed exactly according to an earlier published procedure. ${ }^{34}$

Immunocytochemistry for AIF translocation. Cultured cells were fixed for $20 \mathrm{~min}$ in $4 \%$ paraformaldehyde, washed with PBS and permeabilized with $1 \%$ Triton X-100 for 20 min at room temperature and washed with TBS containing $0.1 \%$ sodium azide. The cells were then incubated with rabbit polyclonal antibody to human AIF (Santa Cruz Biotechnology) overnight at $4^{\circ} \mathrm{C}$. Slides were washed for $30 \mathrm{~min}$ in TBS containing $0.1 \%$ sodium azide and incubated for $1 \mathrm{~h}$ with FITCconjugated secondary antibody and then examined under a Zeiss LSM 510 microscope (Zeiss, Göettingen, Germany).

Detection of autophagic vacuoles. The detection of autophagic vacuoles was carried out with MDC according to an earlier published procedure. ${ }^{35}$ Cells were incubated with $0.05 \mathrm{mM} \mathrm{MDC}$ for $60 \mathrm{~min}$ at $37^{\circ} \mathrm{C}$ followed by fixation in $4 \%$ formaldehyde (15 min), and then washed twice with PBS. The glass coverslips were mounted onto slides using Mowiol as a mounting medium. Analyses were carried out by fluorescent microscopy using a Zeiss LSM 510 microscope (Zeiss). For quantification of MDC fluorescence, floating cells and adherent cells exposed to MDC were combined and an aliquot of 250000 cells was centrifuged for $10 \mathrm{~min}$ at $1000 \times g$. Pelleted cells were exposed to $0.4 \mathrm{ml} \mathrm{lysis} \mathrm{buffer} \mathrm{for} 20 \mathrm{~min}$ at $4{ }^{\circ} \mathrm{C}$ under gentle agitation. Lysates were cleared by centrifugation. The fluorescence was measured using a Wallac Flite 2001 fluorescence reader equipped with an excitation filter of $340 \mathrm{~nm}$ and an emission filter of $535 \mathrm{~nm}$.

ORO and Filipin staining procedures. Cell were grown on glass coverslips and treated with drugs for $72 \mathrm{~h}$ and then fixed with $3.7 \%$ paraformaldehyde for $1 \mathrm{~h}$ at room temperature followed by washing twice with PBS (Euromedex) and stained with ORO in $60 \%(\mathrm{v} / \mathrm{v})$ isopropyl alcohol, and in hematoxylin. Quantification of lipid accumulation was achieved by extracting ORO from stained cells with isopropyl alcohol and measuring the extinction of the extract at $510 \mathrm{~nm}$. The value obtained using a control culture was subtracted from the resulting values. The ORO absorbance was corrected by co-staining DNA with SYBR green dye (Molecular Probes) and quantified on a Labsystems FluoroSkan Ascent FL microplate fluorimeter. Cell number was determined from a standard curve. For filipin staining, the cells grown on glass coverslips were fixed with $3.7 \%$ paraformaldehyde for $15 \mathrm{~min}$ at room temperature followed by washing twice with PBS (Euromedex), and stained with filipin $(50 \mu \mathrm{g} / \mathrm{ml})$ for $75 \mathrm{~min}$ at room temperature followed by washing twice with PBS.

Transmission electron microscopy. Cells were fixed with $2 \%$ glutaraldehyde in $0.1 \mathrm{M}$ Sorensen's phosphate buffer $(\mathrm{pH} 7.4)$ for $1 \mathrm{~h}$ and washed with the Sorensen's phosphate buffer $(0.1 \mathrm{M})$ for $12 \mathrm{~h}$. The cells were then post-fixed with $1 \% \mathrm{OsO}_{4}$ in Sorensen's phosphate buffer (Sorensen's phosphate $0.05 \mathrm{M}$, glucose $0.25 \mathrm{M}, \mathrm{OsO}_{4} 1 \%$ ) for $1 \mathrm{~h}$. The cells were then washed twice with distilled water, and pre-stained with an aqueous solution of $2 \%$ uranyl acetate for $12 \mathrm{~h}$. Samples were then treated exactly as described earlier. ${ }^{5}$

GFP-LC3 staining. MCF-7 cells were transfected with a plasmid expression vector encoding GFP-LC3 (generously provided by Dr P. Codogno) by using FuGENE 6 Transfection Reagent (Roche Applied Science) exactly as published earlier. ${ }^{36}$ At the indicated time after transfection, GFP-LC3 staining was visualized using a Zeiss LSM 510 fluorescent microscope (Zeiss).

Analysis of protein degradation. The long-lived protein degradation was measured as described by Petiot et al. ${ }^{37} \mathrm{MCF}-7$ cells were incubated for $24 \mathrm{~h}$ at $37^{\circ} \mathrm{C}$ with $0.2 \mu \mathrm{Ci} / \mathrm{ml}$ of $\mathrm{L}-\left[{ }^{14} \mathrm{C}\right]$ valine in complete medium. Cells were rinsed three times with PBS ( $\mathrm{pH} 7.4$ ) and then incubated with complete medium supplemented with $10 \mathrm{mM}$ valine. After $1 \mathrm{~h}$ incubation, the medium was replaced by fresh chase medium for $5 \mathrm{~h}$. When required, $40 \mu \mathrm{M}$ PBPE (18h), $10 \mu \mathrm{M}$ Tx (18 h) and 3-MA $(10 \mathrm{mM})$ were added to the chase medium. Cells and radiolabeled proteins from the 5 -h chase medium were precipitated with trichloroacetic acid at a final concentration of $10 \%(\mathrm{v} / \mathrm{v})$ at $4{ }^{\circ} \mathrm{C}$. Radioactivity was measured by liquid scintillation counting. The protein degradation of long-lived proteins was calculated from the ratio of the acidsoluble radioactivity in the medium to that in the acid-precipitable cell fraction.

siRNAs and treatments. Gene expression of endogenous Beclin-1 was suppressed with siRNAs for BECN1 (Santa Cruz Biotechnology, sc-29797) along with a control scrambled sequence siRNA (Santa Cruz Biotechnology, sc-37007).
MCF-7 cells were seeded on six-well plates in RPMI medium containing 5\% FBS. After $24 \mathrm{~h}$ of seeding, cells were transfected in Opti-MEM with $10 \mathrm{nmol} / /$ control siRNA or with $10 \mathrm{nmol} / \mathrm{BECN} 1 \mathrm{siRNA}$ for $4 \mathrm{~h}$ using Oligofectamine (Invitrogen) as recommended by the manufacturer. After $24 \mathrm{~h}$ of siRNA treatment, solvent vehicle, Tx or PBPE was added. At appropriate times, cells were harvested for western blotting, MDC staining or cell death quantification as described above.

Dosage of sterols. Free sterols were extracted from treated MCF-7 cells exactly as described in an earlier paper. ${ }^{10}$ Samples were first passed through a Sep-Pack cartridge (Vac C18 1 cc, Waters) equilibrated with methanol. Reversephase HPLC was carried out with a Perkin-Elmer system (series 200 DAD) coupled to a diode array detector. This system enable us obtain an in-line UV spectrum of the chromatographic peaks. The column, Lichrosorb $\mathrm{C} 185 \mu \mathrm{m}(25 \mathrm{~cm} \times 4 \mathrm{~mm})$, fitted with a Lichrosorb C18 $5 \mu \mathrm{m}(0.5 \mathrm{~cm} \times 4 \mathrm{~mm})$ guard cartridge, was developed isocratically, as described by Kedjouar et a ${ }^{10}$ with methanol/water $(96: 4,(\mathrm{v} / \mathrm{v}))$ at a flow rate of $0.7 \mathrm{ml} / \mathrm{min}$. Quantification of sterols were carried out using a calibration curve established with authentic corresponding sterols.

Data analysis. Statistical analysis was carried out using Student's $t$-test for unpaired variables. ${ }^{\star}$ refers to statistical probabilities $(P)$ of $<0.0001$ compared with the cells that received the drug solvent vehicle as controls.

Acknowledgements. This work was supported by an internal grant from INSERM, the Institut Claudius Regaud, the Conseil Regional Midi-Pyrénnées, the Institut National du Cancer through the ResisTH network and the company Affichem.

1. Sutherland RL, Murphy LC, San Foo M, Green MD, Whybourne AM, Krozowski ZS. Highaffinity anti-oestrogen binding site distinct from the oestrogen receptor. Nature 1980; 288: 273-275

2. Kedjouar B, De Medina P, Oulad-Abdelghani M, Payre B, Silvente-Poirot S, Favre G et al. Molecular characterization of the microsomal tamoxifen binding site. J Biol Chem 2004; 279: 34048-34061.

3. Brandes LJ. A diphenylmethane derivative selective for the anti-estrogen binding site may help define its biological role. Biochem Biophys Res Commun 1984; 124: 244-249.

4. Poirot M, De Medina P, Delarue F, Perie JJ, Klaebe A, Faye JC. Synthesis, binding and structure-affinity studies of new ligands for the microsomal anti-estrogen binding site (AEBS). Bioorg Med Chem 2000; 8: 2007-2016.

5. de Medina P, Favre G, Poirot M. Multiple targeting by the antitumor drug tamoxifen: a structure-activity study. Curr Med Chem Anticancer Agents 2004; 4: 491-508.

6. Reyno L, Seymour L, Tu D, Dent S, Gelmon K, Walley B et al. Phase III study of $N$, $\mathrm{N}$-diethyl-2-[4-(phenylmethyl) phenoxy]ethanamine (BMS-217380-01) combined with doxorubicin versus doxorubicin alone in metastatic/recurrent breast cancer: National Cancer Institute of Canada Clinical Trials Group Study MA.19. J Clin Oncol 2004; 22: 269-276

7. Raghavan D, Brandes LJ, Klapp K, Snyder T, Styles E, Tsao-Wei D et al. Phase II trial of tesmilifene plus mitoxantrone and prednisone for hormone refractory prostate cancer: high subjective and objective response in patients with symptomatic metastases. J Urol 2005; 174: 1808-1813; discussion 1813

8. Liu J, Tu D, Dancey J, Reyno L, Pritchard KI, Pater J et al. Quality of life analyses in a clinical trial of DPPE (tesmilifene) plus doxorubicin versus doxorubicin in patients with advanced or metastatic breast cancer: NCIC CTG Trial MA.19. Breast Cancer Res Treat 2006; 100: 263-271.

9. Payre B, de Medina P, Boubekeur N, Mhamdi L, Bertrand-Michel J, Terce F et al. Microsomal antiestrogen-binding site ligands induce growth control and differentiation of human breast cancer cells through the modulation of cholesterol metabolism. Mol Cancer Ther 2008: 7: 3707-3718.

10. Kedjouar B, Daunes S, Vilner BJ, Bowen WD, Klaebe A, Faye JC et al. Structural similitudes between cytotoxic antiestrogen-binding site (AEBS) ligands and cytotoxic sigma receptor ligands. Evidence for a relationship between cytotoxicity and affinity for AEBS or sigma-2 receptor but not for sigma-1 receptor. Biochem Pharmacol 1999; 58: 1927-1939.

11. Abedin MJ, Wang D, McDonnell MA, Lehmann U, Kelekar A. Autophagy delays apoptotic death in breast cancer cells following DNA damage. Cell Death Differ 2007; 14: 500-510.

12. Castedo M, Ferri K, Roumier T, Metivier D, Zamzami N, Kroemer G. Quantitation of mitochondrial alterations associated with apoptosis. J Immunol Methods 2002; 265: 39-47.

13. Bursch W, Ellinger A, Kienzl H, Torok L, Pandey S, Sikorska M et al. Active cell death induced by the anti-estrogens tamoxifen and $\mathrm{ICl} 164384$ in human mammary carcinoma cells (MCF-7) in culture: the role of autophagy. Carcinogenesis 1996; 17: 1595-1607.

14. Bursch W, Hochegger K, Torok L, Marian B, Ellinger A, Hermann RS. Autophagic and apoptotic types of programmed cell death exhibit different fates of cytoskeletal filaments. J Cell Sci 2000; 113 (Part 7): 1189-1198. 
15. Klionsky DJ, Abeliovich $\mathrm{H}$, Agostinis $\mathrm{P}$, Agrawal DK, Aliev G, Askew DS et al. Guidelines for the use and interpretation of assays for monitoring autophagy in higher eukaryotes. Autophagy 2008; 4: 151-175.

16. Tanida I, Minematsu-Ikeguchi N, Ueno T, Kominami E. Lysosomal turnover, but not a cellular level, of endogenous LC3 is a marker for autophagy. Autophagy 2005; 1: 84-91.

17. Roussi S, Winter A, Gosse F, Werner D, Zhang X, Marchioni E et al. Different apoptotic mechanisms are involved in the antiproliferative effects of 7 beta-hydroxysitosterol and 7 betahydroxycholesterol in human colon cancer cells. Cell Death Differ 2005; 12: 128-135.

18. Kuwana T, Bouchier-Hayes L, Chipuk JE, Bonzon C, Sullivan BA, Green DR et al. BH3 domains of $\mathrm{BH} 3$-only proteins differentially regulate Bax-mediated mitochondrial membrane permeabilization both directly and indirectly. Mol Cell 2005; 17: 525-535.

19. Pacheco CD, Kunkel R, Lieberman AP. Autophagy in Niemann-Pick $C$ disease is dependent upon Beclin-1 and responsive to lipid trafficking defects. Hum Mol Genet 2007 16: $1495-1503$.

20. Liao G, Yao Y, Liu J, Yu Z, Cheung S, Xie A et al. Cholesterol accumulation is associated with lysosomal dysfunction and autophagic stress in $\mathrm{Npc1-I}$ - mouse brain. Am J Pathol 2007; 171: 962-975.

21. Rog T, Pasenkiewicz-Gierula M, Vattulainen I, Karttunen M. Ordering effects of cholesterol and its analogues. Biochim Biophys Acta 2009; 1788: 97-121.

22. Yang $C$, McDonald JG, Patel $A$, Zhang $Y$, Umetani $M, X u F$ et al. Sterol intermediates from cholesterol biosynthetic pathway as liver $X$ receptor ligands. J Biol Chem 2006; 281: 27816-27826.

23. Rodriguez-Acebes S, de la Cueva P, Fernandez-Hernando C, Ferruelo AJ, Lasuncion MA, Rawson RB et al. Desmosterol can replace cholesterol in sustaining cell proliferation and regulating the SREBP pathway in a sterol-Delta24-reductase deficient cell line. Biochem $J$ 2009; 420: 305-315

24. Samaddar JS, Gaddy VT, Duplantier J, Thandavan SP, Shah M, Smith MJ et al. A role for macroautophagy in protection against 4-hydroxytamoxifen-induced cell death and the development of antiestrogen resistance. Mol Cancer Ther 2008; 7: 2977-2987.

25. Luciani P, Deledda C, Rosati F, Benvenuti S, Cellai I, Dichiara F et al. Seladin-1 is a fundamental mediator of the neuroprotective effects of estrogen in human neuroblast longterm cell cultures. Endocrinology 2008; 149: 4256-4266.
26. Kuehnle K, Crameri A, Kalin RE, Luciani P, Benvenuti S, Peri A et al. Prosurvival effect of DHCR24/Seladin-1 in acute and chronic responses to oxidative stress. Mol Cell Biol 2008; 28: $539-550$.

27. Wu C, Miloslavskaya I, Demontis S, Maestro R, Galaktionov K. Regulation of cellular response to oncogenic and oxidative stress by Seladin-1. Nature 2004; 432: 640-645.

28. Motyl T, Gajewska M, Zarzynska J, Sobolewska A, Gajkowska B. Regulation of autophagy in bovine mammary epithelial cells. Autophagy 2007; 3: 484-486.

29. Wu Y, Tibrewal N, Birge RB. Phosphatidylserine recognition by phagocytes: a view to a kill. Trends Cell Biol 2006; 16: 189-197.

30. Atabai K, Sheppard D, Werb Z. Roles of the innate immune system in mammary gland remodeling during involution. J Mammary Gland Biol Neoplasia 2007; 12: 37-45.

31. Collaborative Group on Hormonal Factors in Breast Cancer. Breast cancer and breastfeeding: collaborative reanalysis of individual data from 47 epidemiological studies in 30 countries, including 50302 women with breast cancer and 96973 women without the disease. Lancet 2002; 360: 187-195.

32. Etienne MC, Milano G, Fischel JL, Frenay M, Francois E, Formento JL et al. Tamoxifen metabolism: pharmacokinetic and in vitro study. Br J Cancer 1989; 60: 30-35.

33. Truchet I, Jozan S, Guerrin M, Mazzolini L, Vidal S, Valette A. Interconnections between E2-dependent regulation of cell cycle progression and apoptosis in MCF-7 tumors growing on nude mice. Exp Cell Res 2000; 254: 241-248.

34. de Medina P, Boubekeur N, Balaguer P, Favre G, Silvente-Poirot S, Poirot M. The prototypical inhibitor of cholesterol esterification, Sah 58-035 [3-[decyldimethylsilyl]-n-[2(4-methylphenyl)-1-phenylethyl]propanamide], is an agonist of estrogen receptors. J Pharmacol Exp Ther 2006; 319: 139-149.

35. Biederbick A, Kern HF, Elsasser HP. Monodansylcadaverine (MDC) is a specific in vivo marker for autophagic vacuoles. Eur J Cell Biol 1995; 66: 3-14.

36. Lavieu G, Scarlatti F, Sala G, Carpentier S, Levade T, Ghidoni R et al. Regulation of autophagy by sphingosine kinase 1 and its role in cell survival during nutrient starvation. J Biol Chem 2006; 281: 8518-8527.

37. Petiot A, Ogier-Denis E, Blommaart EF, Meijer AJ, Codogno P. Distinct classes of phosphatidylinositol $3^{\prime}$-kinases are involved in signaling pathways that control macroautophagy in HT-29 cells. J Biol Chem 2000; 275: 992-998. 